\title{
An overview of the lightning and atmospheric electricity observations collected in southern France during the HYdrological cycle in Mediterranean EXperiment (HyMeX), Special Observation Period 1
}

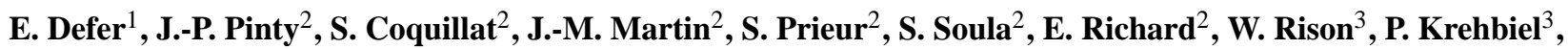 \\ R. Thomas ${ }^{3}$, D. Rodeheffer ${ }^{3}$, C. Vergeiner $^{4}$, F. Malaterre $^{5}$, S. Pedeboy ${ }^{5}$, W. Schulz ${ }^{6}$, T. Farges ${ }^{7}$, L.-J. Gallin ${ }^{7}$, \\ P. Ortéga ${ }^{8}$, J.-F. Ribaud ${ }^{9}$, G. Anderson ${ }^{10}$, H.-D. Betz ${ }^{11}$, B. Meneux ${ }^{11}$, V. Kotroni ${ }^{12}$, K. Lagouvardos ${ }^{12}$, S. Roos ${ }^{13}$, \\ V. Ducrocq ${ }^{9}$, O. Roussot ${ }^{9}$, L. Labatut ${ }^{9}$, and G. Molinié ${ }^{14}$ \\ ${ }^{1}$ LERMA, UMR8112, Observatoire de Paris \& CNRS, Paris, France \\ ${ }^{2}$ LA, UMR5560, Université de Toulouse \& CNRS, Toulouse, France \\ ${ }^{3}$ NMT, Socorro, New Mexico, USA \\ ${ }^{4}$ Institute of High Voltage Engineering and System Performance, TU Graz, Graz, Austria \\ ${ }^{5}$ Météorage, Pau, France \\ ${ }^{6}$ OVE-ALDIS, Vienna, Austria \\ ${ }^{7}$ CEA, DAM, DIF, Arpajon, France \\ ${ }^{8}$ GePaSUD, UPF, Faa'a, Tahiti, French Polynesia \\ ${ }^{9}$ CNRM-GAME, UMR3589, Météo-France \& CNRS, Toulouse, France \\ ${ }^{10}$ UK Met Office, Exeter, UK \\ ${ }^{11}$ nowcast, Garching, Germany \\ ${ }^{12}$ NOA, Athens, Greece \\ ${ }^{13}$ Météo France, Nîmes, France \\ ${ }^{14}$ LTHE, Grenoble, France
}

Correspondence to: E. Defer (eric.defer@obspm.fr)

Received: 2 June 2014 - Published in Atmos. Meas. Tech. Discuss.: 4 August 2014

Revised: 23 November 2014 - Accepted: 15 December 2014 - Published: 9 February 2015

\begin{abstract}
The PEACH project (Projet en Electricite Atmosphérique pour la Campagne HyMeX - the Atmospheric Electricity Project of the HyMeX Program) is the atmospheric electricity component of the Hydrology cycle in the Mediterranean Experiment (HyMeX) experiment and is dedicated to the observation of both lightning activity and electrical state of continental and maritime thunderstorms in the area of the Mediterranean Sea. During the HyMeX SOP1 (Special Observation Period) from 5 September to 6 November 2012, four European operational lightning locating systems (ATDnet, EUCLID, LINET, ZEUS) and the HyMeX lightning mapping array network (HyLMA) were used to locate and characterize the lightning activity over the northwestern Mediterranean at flash, storm and regional
\end{abstract}

scales. Additional research instruments like slow antennas, video cameras, microbarometer and microphone arrays were also operated. All these observations in conjunction with operational/research ground-based and airborne radars, rain gauges and in situ microphysical records are aimed at characterizing and understanding electrically active and highly precipitating events over southeastern France that often lead to severe flash floods. Simulations performed with cloud resolving models like Meso-NH and Weather Research and Forecasting are used to interpret the results and to investigate further the links between dynamics, microphysics, electrification and lightning occurrence. Herein we present an overview of the PEACH project and its different instruments. Examples are discussed to illustrate the comprehensive and 
unique lightning data set, from radio frequency to acoustics, collected during the SOP1 for lightning phenomenology understanding, instrumentation validation, storm characterization and modeling.

\section{Introduction}

A lightning flash is the result of an electrical breakdown occurring in an electrically charged cloud. Charged regions inside the cloud are created through electrification processes dominated by ice-ice interactions. Electrical charges are exchanged during rebounding collisions between ice particles of different nature in the presence of supercooled water. This corresponds to the most efficient non-inductive charging process investigated by Takahashi (1978) and Saunders et al. (1991). Laboratory studies have shown that the transfer of electrical charges between ice particles in terms of amount and sign is very complex and depends on the difference of velocity between the two ice particles, temperature and liquid water content. The lighter hydrometeors are transported upward, the heaviest being sustained at lower altitude in the cloud. Combined with cloud dynamics and cloud microphysics, electrification processes lead to dipoles, tripoles and even stacks of charged zones vertically distributed in the thundercloud (Stolzenburg et al., 1998; Rust et al., 2005). Between the charged regions, the ambient electric field can reach very high values, i.e., more than $100 \mathrm{kV} \mathrm{m}^{-1}$ (Marshall et al., 2005). However, such an electric field intensity is of 1 order of magnitude lower than the electric field threshold required to breakdown cloud air. Therefore, additional ignition mechanisms have been considered, such as runaway electrons (Gurevich et al., 1992) or hydrometeor interactions present in high electric fields (Crabb and Latham, 1974; Coquillat and Chauzy, 1994; Schroeder et al., 1999; Coquillat et al., 2003). Natural lightning flashes then occur when the ambient electric field exceeds a threshold of a few $\mathrm{kV} \mathrm{m}^{-1}$. Hence, it is clear that the lightning activity of a thundercloud results from intricate and complex interactions between microphysical, dynamical and electrical processes.

Lightning flashes are usually classified into two groups: intra-cloud (IC) flashes only occur in a cloud, while cloudto-ground (CG) flashes connect to the ground. Negative (positive) CG flashes lower negative (positive) charge to the ground and exhibit significant electromagnetic radiation when connecting the ground. Negative CG flashes are more frequent than +CG flashes and generally occur with multiple connections to the ground (e.g., Mäkelä et al., 2010; Orville et al., 2011). Positive CG flashes are relatively rare and often composed of a single or very few connections to the ground with higher current than -CG flashes. A natural lightning flash is not a continuous phenomenon but is in fact composed of successive events, also called flash components, with different physical properties in terms of discharge propagation, radio frequency radiation type, current properties, space and time scales. A lightning flash then constitutes a series of multi-scale physical processes spanning from the electron avalanche to the propagation of discharges over large distances of a few kilometers or more. Each of these sub-processes radiates electromagnetic waves in a wide wavelength spectrum.

Different detection techniques have been developed to detect and locate these processes. They usually operate at specific wavelength ranges and are sensitive to some components of the lightning discharges. For instance, some groundbased or space-borne sensors detect electromagnetic radiation emitted in the very high frequency (VHF) domain (e.g., Proctor, 1981; Shao and Krehbiel, 1996; Jacobson et al., 1999; Krehbiel et al., 2000; Defer et al., 2001; Defer and Laroche, 2009). Other instruments detect the radiation emitted by lightning flashes in the optical wavelength (e.g., Light et al., 2001; Christian et al., 2003) or in the very low frequency / low frequency (VLF / LF) range (e.g., Cummins et al., 1998; Smith et al., 2002; Betz et al., 2008, 2009). But because no technique covers all the physical aspects of a lightning flash, multi-instrumental observations are required to provide the most comprehensive description in order to analyze in great detail the lightning flashes and consequently the whole lightning activity of a thunderstorm.

Lightning flashes can be investigated flash by flash to derive their properties. With appropriate lightning sensors such as VHF lightning mappers, the temporal and spatial evolution of the lightning activity can be related to the characteristics of the parent clouds. The total (IC + CG) flash rate is usually a good indicator of the severity of convective systems (Williams et al., 1999). A sudden increase (decrease) of the flash rate is often associated with a more vigorous convection (storm decay). Flash rates usually increase while the storm is developing because conditions for a significant noninductive charging process are favorable. Flash rates reach a peak value when the cloud top reaches its maximum altitude and then decrease at the onset of the decaying stage of the parent thundercloud. Links between severe weather phenomena including lightning flashes, tornadoes, hail storms, wind gusts and flash floods have been studied for many years. As IC observations were not widely recorded and disseminated, numerous investigations used CG reports to predict severe weather (e.g., Price et al., 2011; Kohn et al., 2011). However, in the past decade it has been shown that the total lightning activity is a more reliable indicator of severe weather (e.g., MacGorman et al., 1989; Goodman et al., 1988; Williams et al., 1999; Montanyà et al., 2007). Schultz et al. (2011) report that the use of total lightning trends is indeed more effective than CG trends to identify the onset of severe weather, with an average lead time prior to severe weather occurrence higher when total lightning detection is used as compared to CG detection only. Because detection of the electromagnetic lightning signal can be instantaneously recorded, located and analyzed, flash rate, IC / CG ratio, vertical distribution of the lightning activity, flash duration and flash density can be used 
to identify severe weather in real time but deeper investigations are required.

Having illustrated the potential advantages and the difficulties arising from lightning-storm severity relationships, it is useful to review some available modeling tools to investigate this issue. Among them, 3-D cloud resolving models (CRM) including parameterizations of both electrification mechanisms and lightning discharges are of highest interest. For instance, Mansell et al. (2002) included a very sophisticated lightning flash parameterization in the electrification model of Ziegler et al. (1991). Poeppel (2005) also improved a lightning parameterization in the pioneering model of Helsdon et al. (1987, 2002). Altaratz et al. (2005) concentrated their efforts to test a storm electrification scheme in a regional model (RAMS) but without simulating the lightning flashes, which constitutes by far the most difficult part. More recently, Yair et al. (2010) have developed a method for predicting the potential for lightning activity based on the dynamical and the microphysical fields of the Weather Research and Forecasting (WRF) model. Cloud electrification and discharge processes have also been included recently in the French community model Meso-NH (Molinié et al., 2002; Barthe et al., 2005, 2007; Barthe and Pinty, 2007a, b).

CRMs are the preferred modeling tools to study the sensitivity of the electrical charge structure to the electrification mechanisms (see Barthe et al., 2007a, b). A key challenge in simulating cloud electrification mechanisms is the lack of agreement in the community about the relevance of each of the non-inductive charging diagrams published by Takahashi (1978) and by Saunders et al. (1991). Those diagrams disagree in some way because the protocol of the laboratory experiments was different. As a consequence, changing the non-inductive parameterization rates according to these diagrams deeply modifies the simulated cloud charge structure where regular dipole, inverse dipole or tripole of charge layers can be obtained while keeping the same microphysics and dynamics in the CRMs.

Lightning detection is definitively useful to monitor thunderstorms and to help improve severe weather simulations. Among the open scientific questions related to the electrical activity are the links between microphysics, kinematics and lightning activity, the use of the lightning information in multi-sensor rainfall estimation, and the lightning-flash phenomenology. In the following we describe the rationale for lightning detection to characterize the electrical properties of northwestern Mediterranean storms during a dedicated campaign of the Hydrological cycle in the Mediterranean Experiment (HyMeX) program (Ducrocq et al., 2014). First, the HyMeX project is briefly described in Sect. 2. The scientific questions and the observational strategy of the HyMeX lightning task team, including instruments and models, are described in Sect. 3. Section 4 presents an overview of the observations collected at flash, storm and regional scales. Section 5 then discusses the perspectives by listing out the next steps of the data analysis as well as the data and products made available to the HyMeX community.

\section{The HyMeX program}

The Mediterranean region is regularly affected by heavy precipitation often causing devastating flash floods. Floods and landslides in the Mediterranean basin cost lives and lead to expensive property damage. Improving the knowledge and forecast of these high-impact weather events is a major objective of the HyMeX program (Ducrocq et al., 2014). As part of this 10-year program, the first Special Observation Period (SOP1) HyMeX field campaign was conducted during 2 months from 5 September 2012 to 6 November 2012 over the northwestern Mediterranean Sea and its coastal regions in France, Italy and Spain. The instrumental and observational strategy of the SOP1 campaign was set up to document and improve the knowledge of atmospheric processes leading to heavy precipitation and flash flooding in that specific Mediterranean region. A large battery of atmospheric research instruments were operated during the SOP1 including, among others, mobile weather Doppler and polarimetric radar, airborne radar, in situ microphysics probes, lidar and rain gauges (Ducrocq et al., 2014; Bousquet et al., 2014). These measurement platforms were deployed at or near super sites where dedicated research instruments are gathered to document specific atmospheric processes (Ducrocq et al., 2014). The research lightning sensors operated during the HyMeX SOP1 were located in the Cévennes-Vivarais (CV) area in southeastern France. Additionally, various operational weather forecasting models were used as detailed in Ducrocq et al. (2014).

The HyMeX program (Ducrocq et al., 2014) and its intensive observation period of autumn 2012 was an interesting opportunity to implement multi-instrumental observations for documenting the various processes related to electrification of thunderstorms in a region prone to thunderstorms and high-precipitation events. This was performed during the PEACH (Projet en Electricité Atmosphérique pour la Campagne HyMeX - the Atmospheric Electricity Project of the HyMeX Program) experiment, the HyMeX atmospheric electricity component, as detailed in the following.

\section{The PEACH experiment}

Summer electrical activity is predominately located over continental Europe while during the winter the electrical convective clouds are mainly observed over the Mediterranean Sea, as established by climatology based on lightning records (e.g., Holt et al., 2001; Christian et al., 2003; Defer et al., 2005) or on space-based microwave measurements (e.g., Funatsu et al., 2009). Holt et al. (2001) discussed that the largest number of days with thunderstorms over the Mediterranean basin is located near the coasts of Italy and Greece. Based on 
3 years of Tropical Rainfall Measurement Mission (TRMM) lightning imaging sensor (LIS) observations, Adamo (2004) reported that the flash rates over the Mediterranean Sea are significantly smaller than those recorded at similar latitudes in the United States. This finding is consistent with the fact that convection and consequently lightning activity are significantly stronger over land than over sea (Christian et al., 2003).

Current geostationary satellites can offer a relatively satisfying revisiting time $(15 \mathrm{~min})$ to track the storms but cannot provide sounding information below the cloud top. Spacebased passive and active microwave sensors on low-orbit satellite missions such as TRMM (Kummerow et al., 1998) or A-Train (Stephens et al., 2002) only provide a scientifically relevant snapshot of the sampled clouds, but the ability of low-orbit instruments to monitor and track weather systems is very limited. Lightning detection data from groundbased detection networks are available continuously and instantaneously over the continental and maritime Mediterranean area as detailed in the following. Lightning information can monitor severe weather events over continental and maritime Mediterranean region but can also improve weather forecasts with lightning data assimilation (Lagouvardos et al., 2013). However, further scientific investigations are required to document the links between the lightning activity and the dynamical and microphysical properties of the parent clouds in continental and maritime Mediterranean storms. In addition, it is necessary to identify the key parameters derived from operational lightning locating systems (OLLS) records alone or in combination with other meteorological observations to provide suitable proxies for better storm tracking and monitoring over the entire Mediterranean basin.

\subsection{Scientific objectives and observational/ modeling strategy}

In the frame of the HyMeX program, several international institutes joined their effort to investigate the lightning activity and the electrical state of thunderstorms. This topic is part of the HyMeX working group WG3 dedicated to the study of heavy precipitation events (HPEs), flash floods and floods. The PEACH team, composed of the authors of the present article, identified five observational- and modeling-based scientific objectives in relation to HyMeX goals:

1. Study the relationships between kinematics, microphysics, electrification, aerosols, and lightning occurrence and characteristics;

2. Document the electrification processes and charge structures inside clouds over sea and land, and during sea-to-land and land-to-sea transitions;

3. Promote the use of lightning records for data assimilation, nowcasting and very short-range forecasting applications;
4. Cross-evaluate lightning observations from different OLLSs;

5. Establish climatology of lightning activity over the Mediterranean basin.

The first three scientific objectives exhibit obvious connections to WG3 objectives to document and understand thunderstorms leading to HPEs and flash floods and to explore the pertinence of lightning detection in conjunction (or not) with operational weather observations to improve monitoring and forecasting of the storm activity. The fourth objective focuses on the intercomparison of OLLS records to objectively evaluate what each OLLS technology reports, as lightning detection (with a quasi-instantaneous data delivery to the users) and geostationary imagery are the only two weather-observing techniques readily available over the full Mediterranean basin. The fifth objective aims to document long-term series of lightning-based proxies of thunderstorms during the 10-year duration of the HyMeX program but also from more than 2 decades of past lightning data available from some European OLLSs.

The PEACH observational strategy followed the HyMeX observational strategy with SOP (Special Observation Period), EOP (Enhanced Observation Period) and LOP (Long Observation Period) activities. SOP1 activities are mainly described here while EOP and LOP are briefly discussed as they are still underway at the time of this writing. The SOP1 PEACH strategy consisted of deploying relevant instrumentation from September to November 2012 in key locations together with instruments operated by other HyMeX teams with common temporal and spatial coverage over the CV domain. First, OLLSs with continuous, good-quality coverage of the Mediterranean were identified. Then a total-lightning detection system was considered and a portable lightning mapping array (HyLMA) was selected. Electric field mills (EFMs), slow antennas (SLAs) and induction rings (INRs) were also listed as key instruments for characterizing the ambient electric field, the change of the electric field induced by the lightning occurrence and the electrical charges carried by raindrops at ground level, respectively. Finally, in order to increase the scientific returns, additional research field instruments were operated, including a mobile optical camera combined with electric field measurement (VFRS, video and field record system), microbarometer and microphone arrays (MBA and MPA, respectively) and transient luminous event cameras (Fullekrug et al., 2013). The PEACH project also includes two cloud resolving models, Meso-NH (with its electrification and lightning scheme) and WRF.

As discussed in Duffourg and Ducrocq (2011) and Ducrocq et al. (2014), the southeastern part of France has previously experienced heavy precipitation with devastating flash floods, floods and landslides. The PEACH observational setup in conjunction with the other HyMeX research and operational instrumentation aims at documenting the lightning activity existing, or not, in those heavy- 
precipitation systems. The HyLMA observations combined with the OLLS records provide the required accurate description of the lightning activity (e.g., flash rate, flash density, IC / CG ratio, vertical and horizontal flash development) to investigate its relationships with the dynamical and microphysical cloud properties in combination with ground-based and airborne radars and in situ measurements. Such an investigation is the basis for developing new lightning-based tools for nowcasting and very short-range forecasting applications. In addition, the HyLMA observations, whether in conjunction or not with ground-based electric field measurements, help to investigate the temporal and spatial evolution of the charge structures inside the clouds, over sea and land, as deduced from the properties of the VHF signal radiated by the different flash components. The capability to map with HyLMA the 3-D structure of the lightning flashes, as well as the regions of electrical charges in the thunderclouds, allows the validation of lightning/electrification schemes implemented in numerical cloud resolving models and the investigation of new lightning data assimilation schemes. Finally, to establish a solid climatology of lightning activity over the Mediterranean basin from more than 2 decades of OLLS records, the study of concurrent HyLMA, OLLSs and VFRS records is required not only to access the actual performances of the OLLSs but also to determine precisely the flash components that OLLSs record with the perspective of a better operational use of OLLS observations.

As a result, the HyMeX SOP1 experiment is probably the first ambitious field experiment in Europe to offer such comprehensive descriptions of lightning activity and of its parent clouds over a mountainous area from the early stage to the decaying phase of the sampled electrical storms. Note that a battery of ground-based and airborne research radars in conjunction with the operational network of Météo-France provided a detailed description of the thunderclouds as detailed in Bousquet et al. (2014). Other instruments were deployed as listed in Ducrocq et al. (2014). In this article we give some examples only of atmospheric electricity observations. Several studies are underway on the electrical properties of thunderstorms relative to cloud properties like cloud structure, microphysics and rain patterns, as derived from radar and satellite observations and in situ measurements.

\subsection{Research instruments deployed during the SOP1}

\subsubsection{The HyMeX lightning mapping array}

A 12-station lightning mapping array (Rison et al., 1999; Thomas et al., 2004) was deployed in the HyMeX SOP1 area from spring to autumn 2012 (Fig. 1). The HyLMA stations, located in radio-frequency-quiet (RF-quiet), mainly rural areas, were solar powered and used broadband cell phone modems for communications. Each HyLMA station recorded the arrival times and amplitudes of the peaks of impulsive VHF sources, recording at most one peak in every $80 \mu$ s in-

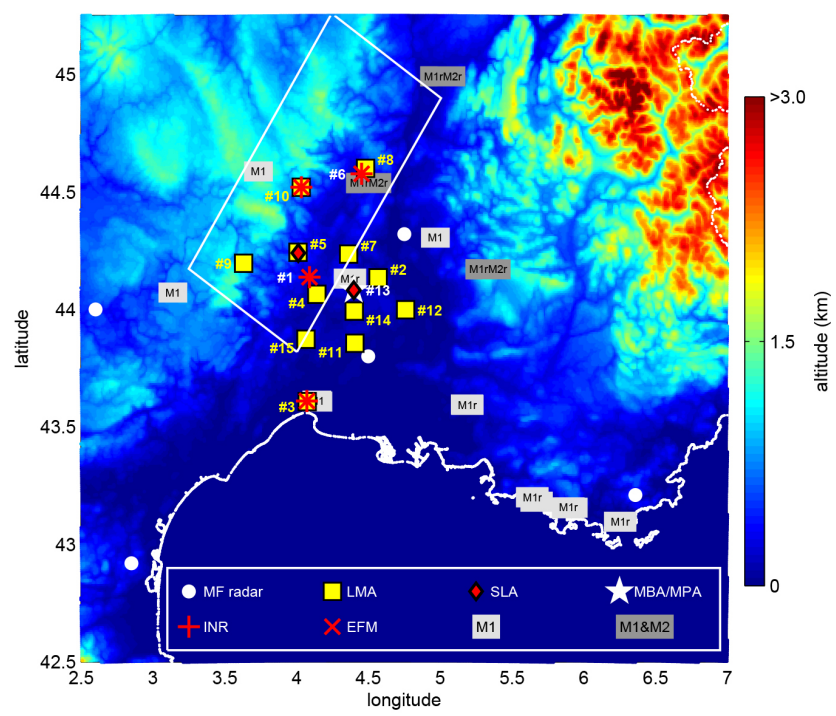

Figure 1. Locations of PEACH instrumental sites (see Table 1 for details on site locations). M1 markers indicate VFRS locations while M2 markers indicate the few locations where a second video camera was operated at the same site; sites where VFRS recorded actual lightning flashes are labeled with an extra letter " $r$ ". The Cévennes-Vivarais domain is also delimited by the white polygon.

terval. Locations of impulsive VHF sources were determined by correlating the arrival times for the same event at multiple stations (Thomas et al., 2004). Every minute, a subset of the raw data (the peak in every $400 \mu$ s interval) was transferred to a central computer for real-time processing and display. The full data were retrieved at the end of the project for detailed post-processing.

An LMA locates the strongest VHF source in every $80 \mu$ s interval. Because negative leaders radiate much more strongly than positive leaders and negative and positive leaders typically propagate at the same time, an LMA primarily locates lightning channels from negative leaders. In particular, an LMA rarely detects the positive leaders from positive cloud-to-ground strokes.

The HyLMA detected all lightning over the array with a location accuracy of about $10 \mathrm{~m}$ horizontally and $30 \mathrm{~m}$ vertically (Thomas et al., 2004). The HyLMA located much of the lightning outside of the array, with increasingly large location errors $(<1 \mathrm{~km}$ at $200 \mathrm{~km}$ range) out to a distance of about $300 \mathrm{~km}$ from the array center. In order to locate a source, at least six stations must have line of sight to that source. The lines of sight of most of the stations to low-altitude lightning channels outside of the array were blocked by the mountainous terrain in southeastern France, so the LMA typically detected only the higher altitude lightning channels outside the array. 


\subsubsection{Slow antennas}

Two solar-powered slow antennas were deployed to measure the electrostatic field changes from lightning in the SOP1 area. One SLA was deployed a few tens of meters from the MBA/MPA (see Sect. 3.2.3) near the Uzès airfield, and the second was deployed near the HyLMA station at La GrandeCombe airfield. Each SLA consisted of an inverted flat-plate antenna connected to a charge amplifier with a $10 \mathrm{~s}$ decay constant. The output of the charge amplifier was digitized at a rate of 50000 samples per second with a 24 bit A/D converter synchronized to a local GPS receiver, and the data were recorded continuously on SD cards.

\subsubsection{The microbarometer and microphone arrays}

The CEA (Commissariat à l'Energie Atomique et aux Energies Alternatives) team installed two arrays that overlapped each other: an MBA and MPA. The MBA was composed of four MB2005 microbarometers arranged in an equilateral triangle with sides of about $500 \mathrm{~m}$ long with one at the barycenter of the triangle, while the MPA was composed of four microphones arranged in an equilateral triangle with sides of about $52 \mathrm{~m}$ long with one at the barycenter of the triangle. The MBA and MPA barycenters were localized at the same place.

Each sensor measures the pressure fluctuation relative to the absolute pressure. The MB2005 microbarometer has a sensitivity of a few millipascals through a band pass of $0.01-$ $27 \mathrm{~Hz}$. This sensor is used in most of the infrasound stations of the international monitoring system of the Comprehensive Nuclear-Test-Ban Treaty Organization (www.ctbto.org). The microphone is an encapsulated BK4196 microphone. Its sensitivity is about $10 \mathrm{mPa}$ through a band pass of $0.1-70 \mathrm{~Hz}$. In order to minimize the noise due to surface wind effects, each sensor is connected to a noise-reducing system equipped with multi-inlet ports (eight for the microbarometers and four for the microphones) that significantly improve the detection capability above $1 \mathrm{~Hz}$. To further reduce the wind noise, microbarometers were installed under vegetative cover (i.e., pine forest).

The signal from these sensors was digitalized at $50 \mathrm{~Hz}$ for the MBA and $500 \mathrm{~Hz}$ for the MPA. The dating was GPS tagged. Data were stored on a hard disk. No remote access was possible during the SOP1. To avoid power blackouts, each measurement point was supplied with seven batteries. Those batteries needed to be recharged in the middle of the campaign, meaning that the MBA and MPA were unavailable from 9 to 12 October.

The data from each sensor of the arrays were compared using cross-correlation analysis of the waves recorded. The azimuth and the trace velocity were calculated for each detected event when a signal was coherent over the array. Using the time of the lightning discharge and these parameters, a 3$\mathrm{D}$ location of acoustic sources generated by the thunder was possible (e.g., MacGorman et al., 1981; Farges and Blanc, 2010; Arechiga et al., 2011; Gallin, 2014). Gravity waves generated by thunderstorms (Blanc et al., 2014) could also be monitored by MBA. When a convective system goes over an array, a large pressure variation was measured.

\subsubsection{Electric field mills}

The surface electrostatic field can be used to detect the presence of charge overhead within a cloud. This parameter is generally measured with a field mill and the value obtained can be very variable according to the sensor shape and location, the relief of the measurement site, the nature of the environment, etc. The field value and its evolution must be interpreted very carefully due to the variety of sources of charge: the cloud charge, the space charge layer that can develop above ground from corona effect on the ground irregularities and the charge carried by the rainfall (Standler and Winn, 1979; Chauzy and Soula, 1987; Soula et al., 2003). However, the electric field evolution can be used to identify discontinuities due to the lightning flashes, which can be related to the flashes detected by location systems (Soula and Georgis, 2013).

The field mills used at three of the stations were Previstorm models from Ingesco Company and were initially used by Montanya et al. (2009). The measurement head is oriented downward to avoid rain disturbances and is fixed at the top of a $1 \mathrm{~m}$ mast that reinforces the electrostatic field on the measuring electrode. The measuring head of the fourth field mill was orientated upward and flush to the ground thanks to a hole dug in the ground. The field mills were calibrated to zero by using a shielding and by considering the fair weather conditions that correspond to the theoretical value of $130 \mathrm{~V} \mathrm{~m}^{-1}$. The data from each sensor were recorded with a time resolution of $1 \mathrm{~s}$. This time resolution readily revealed the major discontinuities in the electrostatic field caused by the lightning flashes without the distracting effects of much faster individual processes within a flash. The polarity of the field was positive when the field points upward and the electric field was created by negative charge overhead.

\subsubsection{Induction rings}

The electric charge carried by raindrops can easily be detected and measured by an INR, a simple apparatus. This sensor consists of a cylindrical electrode (the ring) on the inner surface, where induced electric charges appear by electrostatic influence when a charge raindrop enters the sensor. When the drop leaves the sensor, the induced charges disappear. The cylindrical electrode is connected to an electrometer and the current signal induced by the passing of a charged drop (a bipolar current impulse) is sampled at a rate of $2000 \mathrm{~Hz}$. It is amplified and integrated by an electronic circuitry that directly provides the charge signal. This one appears as a single pulse with amplitude and length propor- 
Table 1. Site ID numbers and locations of the PEACH SOP1 instruments. Sites of VFRS records are not indicated here. MF stands for Météo-France; EMA for Ecole des Mines d'Alès.

\begin{tabular}{|c|c|c|c|c|c|c|c|c|}
\hline \multirow[b]{2}{*}{ ID \# } & \multirow[b]{2}{*}{ Location } & \multirow[b]{2}{*}{ Type } & \multirow[b]{2}{*}{ Owner } & \multicolumn{5}{|c|}{ Instruments } \\
\hline & & & & LMA & SLA & MBA/MPA & INR & EFM \\
\hline 1 & Alès & Building roof & EMA school & & & & $\mathrm{X}$ & $\mathrm{X}$ \\
\hline 2 & Cadignac & Land & Private & $\mathrm{X}$ & & & & \\
\hline 3 & Candillargues & Airfield & Local administration & $\mathrm{X}$ & & & $\mathrm{X}$ & $\mathrm{X}$ \\
\hline 4 & Deaux & Airfield & Local administration & $X$ & & & & \\
\hline 5 & La Grande-Combe & Airfield & MF/local administration & $X$ & $\mathrm{X}$ & & & \\
\hline 6 & Lavilledieu & Building roof & Elementary school & & & & $\mathrm{X}$ & $\mathrm{X}$ \\
\hline 7 & Méjannes-le-Clap & Land & Local administration & $\mathrm{X}$ & & & & \\
\hline 8 & Mirabel & Land & Private & $X$ & & & & \\
\hline 9 & Mont Aigoual & Land & Private & $X$ & & & & \\
\hline 10 & Mont Perier & Land & Private & $\mathrm{X}$ & & & $\mathrm{X}$ & $\mathrm{X}$ \\
\hline 11 & Nîmes & Land & MF & $\mathrm{X}$ & & & & \\
\hline 12 & Pujaut & Airfield & MF & $\mathrm{X}$ & & & & \\
\hline 13 & Uzès - north & Airfield & Private & & $\mathrm{X}$ & $\mathrm{X}$ & & \\
\hline 14 & Uzès - south & Land & MF & $\mathrm{X}$ & & & & \\
\hline 15 & Vic-le-Fesq & Land & Private & $X$ & & & & \\
\hline
\end{tabular}

tional to the charge and to the velocity of the drop, respectively. The actual charge is deduced from the calibration of the sensor. If the drop collides with the induction cylinder, the pulse signal exhibits a slow exponential decay (MacGorman and Rust, 1998) that is easily recognizable in the data post-processing. In this case, the raindrop charge that is fully transferred to the induction cylinder is determined by a specific calibration. The charge measurement sensitivity ranges from about \pm 2 to $\pm 400 \mathrm{pC}$. Furthermore, the charge signal duration at mid-height can be used to determine the size of the charged raindrops, providing the relationship between size and fall velocity is a function of the actual temperature and pressure (Beard, 1976).

Such a measurement provides key information on the electric charge carried by the rain at the ground to validate numerical modeling. It documents the spectrum of charged drops and helps deduce the proportion of charged drops within the whole drop population by comparing its spectrum with the one measured by a disdrometer. Four INRs were built and operated during the SOP1, mainly along the south-north axis at the foothills of the Massif Central where most high-precipitation events occur. Unfortunately, only a few events passed above the sensors and, in these rare cases, the main electronic component of the INRs suffered a malfunction that was not detected during the laboratory tests, so no valuable INR data are available for the SOP1.

\subsubsection{Video and field recording system}

The VFRS instrument is a transportable system used to measure electric fields and to record high-speed videos at various locations. The calibrated $E$ field measurement consists of a flat-plate antenna, an integrator-amplifier, a fiber optic link and a digitizer. The bandwidth of the $E$ field measurement ranged from about $350 \mathrm{~Hz}$ to about $1 \mathrm{MHz}$. A 12 bit digitizer with a sampling rate of $5 \mathrm{MS} \mathrm{s}^{-1}$ was used for data acquisition. The high-speed camera was operated at $200 \mathrm{fps}$ (equivalent to an exposure of $5 \mathrm{~ms}$ frame $^{-1}$ ), $640 \times 480$ pixel and 8 bit grayscale resolution. The GPS clock provided an accurate time stamp for the $E$ field and the video data. The range of the VFRS was mainly dependent on the visibility conditions. At adequate visibility, combined video and electric field data could record flashes with sufficient quality up to $50 \mathrm{~km}$ range. The VFRS was transportable with a car and independent of any external power supply. A detailed description of the used VFRS can be found in Schulz et al. (2005) and in Schulz and Saba (2009). For the typical observations during SOP1, the VFRS was operated in the manual trigger mode using an adjustable pre- and posttrigger. To ensure capturing the entire lightning discharge we typically recorded $6 \mathrm{~s}$ of data with $2 \mathrm{~s}$ of pre-trigger data per observed flash. During some storms (e.g., low-visibility conditions) the VFRS was operated in the continuous recording mode. Due to memory limitations we only recorded the electric fields in continuous recording mode.

All observation days during SOP1 were chosen based on weather forecasts with sufficient thunderstorm risk over the region of interest. As the real situation could be different to the forecast scenario - e.g., location, motion and stage of the storms - the VFRS sometimes had to be moved from the initial site to another one. For each field operation, the lightning activity of the targeted thunderstorm was monitored in real time using EUCLID and HyLMA observations. The VFRS was often deployed at several sites during a typical observation day. An observation day was finished when no more thunderstorms were expected to occur. 


\subsubsection{Locations and status of the research instruments}

Figure 1 presents the locations of the different PEACH instruments operated during SOP1. The HyLMA network consisted of a dense eight-station network more or less centered on Uzès (Gard) with four additional remote stations located on the western side of the CV domain. SLA antennas were deployed in two different locations: one at the center of the HyLMA network, a few tens of meters away from MPA and MBA, and a second one in the hills, a few hundred meters away from La Grande-Combe HyLMA station (Table 1). INR and EFM were installed on the same sites with other HyMeX SOP1 instruments like the rain gauge, videodistrometers and micro rain radar (MRRs; Bousquet et al., 2014). VFRS observations were performed at different locations during the SOP1 according to the forecast and the evolution of the storm activity, with guidance from HyMeX operation center and members of the lightning team. Finally, the four OLLSs continuously covered the entire SOP1 domain.

Table 2 shows the status of the instruments during the SOP1 and after its completion. HyLMA was initially operational with six stations starting on 1 June 2012 and expanded to 11 stations starting early August 2012. The 12th HyLMA station was online early September 2012. Low timeresolution ( $400 \mu$ s time window) HyLMA lightning observations were delivered in real time during the SOP1 through wireless communication and displayed on the HyMeX operation center website as well as on a dedicated server at NMT. The full HyLMA data were reprocessed after the completion of the SOP1 campaign and only high-temporal resolution HyLMA data are used in the analysis and distributed to the HyMeX community. Additionally, ATDnet, EUCLID and ZEUS observations were also delivered in real time to the HyMeX operation center.

\subsection{Operational lightning locating systems}

\subsubsection{ATDnet}

The UK Met Office VLF ATDnet (Arrival Time Differencing NETwork) lightning location network takes advantage of the long propagation paths of VLF sferics $(12.5-14.9 \mathrm{kHz})$ emitted by lightning discharges that propagate over the horizon via interactions with the ionosphere (Gaffard et al., 2008). The ATDnet network consists of 11 that regularly contribute to the "operational network", plus sensors distributed further afield. The waveforms of VLF sferics received at the ATDnet sensors are transmitted to a central processor in Exeter, where the waveforms are compared in order to estimate arrival time differences. These arrival time differences are compared with theoretical arrival time differences for different locations in order to estimate the most likely source location. Current ATDnet processing requires four ATDnet sensors to detect a lightning stroke in order to be able to calculate a single, unambiguous source location. ATDnet predominantly detects sferics created by CG strokes, as the energy and polarization of Sferics created by $\mathrm{CG}$ return strokes can travel more efficiently in the Earth-ionosphere waveguide and so are more likely to be detected at longer ranges than typical IC discharges. ATDnet location uncertainties within the region enclosed by the network of sensors are on the order of a few kilometers, i.e., suitable for identifying electrically active cells.

\subsubsection{EUCLID}

The EUCLID network (EUropean Cooperation for LIghtning Detection) is a cooperation of several European lightning detection networks (Austria, Finland, France, Germany, Italy, Norway, Portugal, Slovenia, Spain and Sweden) that operate state-of-the-art lightning sensors. As of August 2009 the EUCLID network employs 137 sensors, 5 LPATS III, 18 LPATS IV, 15 IMPACT, 54 IMPACT ES/ESP, 3 SAFIR and 42 LS7000 sensors (oldest to newest), all operating over the same frequency range $(1-350 \mathrm{kHz})$ with individually calibrated gains and sensitivities. Data from all of these sensors are processed in real time using a single common central processor that also produces daily performance analyses for each of the sensors. This assures that the resulting data are as consistent as possible throughout Europe. In fact, the Europe-wide data produced by EUCLID are frequently of higher quality than the data produced by individual country networks due to the implicit redundancy produced by shared sensor information. Since the beginning of the cooperation, the performance of the EUCLID network has steadily improved, e.g., with improved location algorithms, with newer sensor technology and by adapting sensor positions because of bad sites. The flash/stroke detection efficiency (DE) of the EUCLID network in the south of France was determined to be $90 / 87 \%$ for negative and $87 / 84 \%$ for positive discharges but for a time period where a close sensor was out of order (Schulz et al., 2014). Therefore the values should be rated as lower limits of EUCLID DE in this region. The location accuracy was determined to be $256 \mathrm{~m}$ but based on 14 strokes only.

\subsubsection{LINET}

The LINET system is a modern lightning detection network in the VLF/LF domain $(5-100 \mathrm{kHz})$ developed by nowcast GmbH (Betz et al., 2008, 2009). LINET Europe consists of more than 120 sensors placed in 25 countries. Each sensor includes a field antenna, a GPS antenna and a field processor. The field antenna measures the magnetic flux produced by a lightning discharge. The processor evaluates this signal and combines it with the accurate time provided by the GPS antenna. Compact data files are then sent to a central processing unit where the final stroke solutions are generated. Accurate location of strokes requires that the emitted sig- 
Table 2. Status of the instruments during HyMeX SOP1.

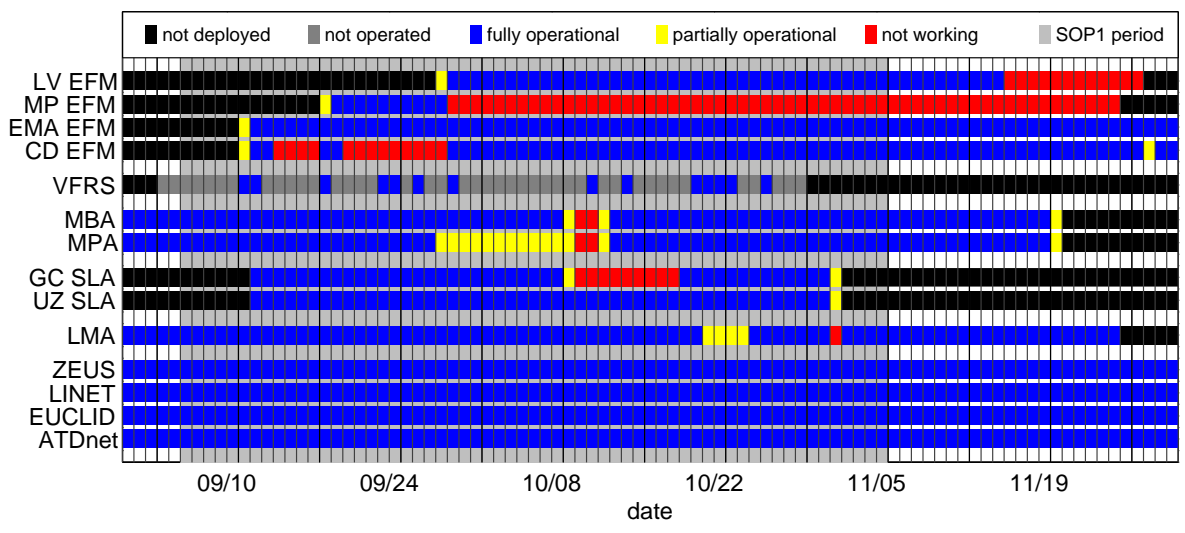

nal is detected by many sensors. Reported strokes are based on reports from at least five sensors. Strokes are located using the time-of-arrival (TOA) method. LINET also detects cloud strokes and can distinguish between CG strokes and IC strokes. Typical baseline of LINET systems are $200 \mathrm{~km}$ between adjacent sensors, allowing very good detection efficiency even for very weak strokes $(<10 \mathrm{kA})$, whereby an average statistical location accuracy of $\sim 200 \mathrm{~m}$ is achieved. However, in the HyMeX area in southern France the baselines are longer and thus the efficiency is somewhat lower than in most other LINET network areas.

\subsubsection{ZEUS}

The ZEUS network is a long-range lightning detection system operated by the National Observatory of Athens. The ZEUS system comprises six receivers deployed in Birmingham (UK), Roskilde (Denmark), Iasi (Romania), Larnaca (Cyprus), Athens (Greece) and Lisbon (Portugal), the last being relocated to Mazagón (Spain). ZEUS detects the impulsive radio noise emitted by a lightning strike in the very low frequency (VLF) spectrum between 7 and $15 \mathrm{kHz}$. At each receiver site an identification algorithm is executed that detects a probable sferics candidate, excludes weak signal and noise and is capable of capturing up to 70 sferics per second. Then the lightning location is retrieved (at the central station) using the arrival time difference technique. Further details on the ZEUS network are given in Kotroni and Lagouvardos (2008). Lagouvardos et al. (2009) have compared the ZEUS system with the LINET system over a major area of central-western Europe, where the latter system presents its major efficiency and accuracy, and found that the location error of ZEUS was $6.8 \mathrm{~km}$ and the detection efficiency $25 \%$. These numbers are also applicable for the SOP1 domain. The authors also found that while ZEUS detects cloud-to-ground lightning it is also capable of detecting strong IC lightning. At this point it should be stated that the statistical analysis showed that ZEUS is able to detect, with high accuracy, the occurrence of lightning activity although it underdetects the actual number of strokes.

\subsection{Instrumentation during EOP and LOP}

The only instruments operated so far during EOP and LOP are the OLLSs due to their operational design. For instance, ZEUS observations are continuously delivered in real time to the HyMeX LOP website, while EUCLID and ATDnet produce daily maps of the lightning activity over the Mediterranean basin that are delivered to the HyMeX database. During spring 2014, a network of 12 LMA stations was deployed permanently in Corsica to contribute to the HyMeX LOP efforts in that specific region of the Mediterranean Sea.

\subsection{Modeling}

\subsubsection{The Meso-NH model}

The 3-D cloud-resolving mesoscale model Meso-NH (see http://mesonh.aero.obs-mip.fr) contains CELLS, an explicit scheme to simulate the cloud electrification processes (Barthe et al., 2012). This electrical scheme was developed from a one-moment microphysical scheme of MesoNH to compute the non-inductive charge separation rates (for which several parameterizations are available), the gravitational sedimentation of the charges and the transfer rates as the electrical charges evolve locally according to the microphysical mass transfer rates. The charges are transported by the resolved and turbulent flows. They are carried by cloud droplets, raindrops, pristine ice crystals, snow-aggregates, graupel and two types of positive/negative free ions to close the charge budget. The electric field is computed by inverting the Gauss equation on the model grid (vertical terrainfollowing coordinate). It is updated at each model time step and also after each flash when several of them are triggered in a single time step. The lightning flashes are treated in a rather coarse way. They are triggered when the electric field reaches the break-even field. A vertically propagating leader 
is then first initiated to connect the triggering point to the adjacent main layers of charges upwards and downwards. Then the flash propagates horizontally along the layers of charges using a fractal scheme to estimate the number of model grid points reached by the flash path. The flash extension is limited by the geometry of the charged areas and the cloud boundaries. Finally an equal amount of positive and negative charges are partially neutralized at model grid points where an IC flash goes through. In contrast, the CG flashes, detected when the height of the downward tip of the first leader goes $1500 \mathrm{~m}$ a.g.l., are polarized since they are not constrained by a neutralization requirement.

\subsubsection{The WRF model}

The PEACH team has already explored the use of available observational and modeling tools to improve the monitoring, understanding and forecasting of a SOP-like heavy precipitation event over southern France (Lagouvardos et al., 2013). More specifically, the authors applied an assimilation technique that controls the activation of the convective parameterization scheme using lightning data as proxy for the presence of convection in an MM5 mesoscale model. The assimilation of lightning proved to have a positive impact on the representation of the precipitation field, also providing more realistic positioning of the precipitation maxima.

Following this example, various simulations of SOP1 case studies are expected to be performed based on WRF model. The WRF model (Skamarock et al., 2008) is a community mesoscale NWP model designed to be a flexible, state-ofthe-art tool that is portable and computationally efficient on a wide variety of platforms. It is a fully compressible nonhydrostatic model with a terrain following a hydrostatic pressure vertical coordinate system and Arakawa $\mathrm{C}$ grid staggering. It is in the authors' plans to also investigate the ability of WRF model to predict the spatial and temporal distribution of lightning flashes based on the implemented scheme proposed by Barthe and Barth (2008), where the prediction of lightning flash rate is based on the fluxes of non-precipitating and precipitating ice.

\section{Observations collected during the HyMeX SOP1}

The following section presents an overview of observations collected by different PEACH instruments and demonstrates the rather comprehensive and unique data set of natural lightning flashes collected so far in Europe. The different examples shown here are not related to any other HyMeX SOP1 observations as the main goal of the paper focuses on the actual PEACH observations and their consistency. Several studies are already underway to relate the lightning activity and the electrical properties to microphysical and dynamical properties of the parent thunderclouds using observations from operational and research radars (e.g., Bousquet et al.,
2014), in situ airborne and ground-based probes and satellites, and numerical simulations.

\subsection{SOP1 climatology}

Figure 2 shows a comparison of the lightning activity as sensed by Météorage, the French component of the EUCLID network, over southeastern France for the period SeptemberOctober-November (SON) 2012 and for the period 19972012. It is based on the number of days with at least one lightning flash recorded per day in a regular grid of $5 \mathrm{~km} \times 5 \mathrm{~km}$ and cumulated over the period investigated. Only flashes identified as CG flashes by Météorage algorithms are considered here. A similar climatology, but for the period 19972011, was used to determine the most statistically electrically active area in the field domain to deploy and operate the lightning research sensors. Although further investigations on the climatologic properties of the lightning activity are underway, Fig. 2b shows the contribution of the 2012 records to the period 1997-2012. The year 2012 was rather weak in terms of lightning activity over the center of the SOP1 domain. The electrical activity was mainly located in the far northern part of $\mathrm{CV}$ domain and was more pronounced along the Riviera coastline and over the Ligurian Sea (Fig. 2b). About $0.3 \%$ of the $5 \mathrm{~km} \times 5 \mathrm{~km}$ pixels of the year 2012 contribute to more than $20 \%$ of the 16 -year climatology. Over the $500 \mathrm{~km}$ side domain plotted in Fig. 2a and $\mathrm{b}$ and for a period ranging from 5 September to 6 November, the total number of days with lightning activity in 2012 reached a value of 44 days, slightly below the average value for the 16 years of interest (Fig. 2c). Even if the lightning activity was less pronounced in 2012 over the CV domain, electrical properties of several convective systems were documented during SOP1 as shown in the following as well as in Ducrocq et al. (2014) and Bousquet et al. (2014). HyLMA also captured summer thunderstorms as it was already operated before the SOP1. During the deployment of the HyLMA network, and based on the experience gained during the Deep Convective Clouds and Chemistry (DC3) project, it was decided to enhance the actual coverage of the HyLMA network by deploying four of the 12 stations (Candillargues, Mont Aigoual, Mont Perier, Mirabel) away from the dense eight-station network. The redeployment to the west was also strongly recommended by the local Weather Office to document the growth of new electrical cells within V-shape storm complexes that usually occur in the southwestern zone of the field domain. Interestingly, this new configuration offered the possibility to record farther lightning activity in all directions. 

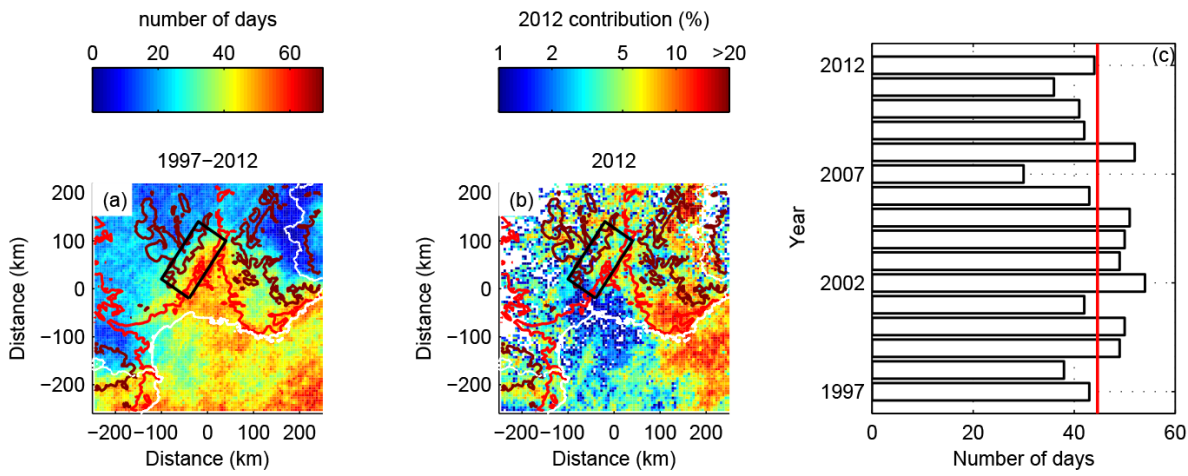

Figure 2. Cloud-to-ground lightning climatology in terms of number of days with at least one cloud-to-ground lightning flash recorded per day in a regular grid of $5 \mathrm{~km} \times 5 \mathrm{~km}$ and cumulated over the period investigated as sensed by Météorage from 1997 to 2012 (a), contribution of the 2012 records expressed in \% relative to the 1997-2012 number of days per $5 \mathrm{~km} \times 5 \mathrm{~km}$ pixel (b) and number of days per year (c) for the period September-November over southeastern France. The red solid line plotted in (c) corresponds to the average value for the 1997-2012 period. Red and black red lines in (a) and (b) indicate 200 and $1000 \mathrm{~m}$ height, respectively. The Cévennes-Vivarais domain is also delimited by the black polygon.

\subsection{Examples of concurrent PEACH observations}

\subsubsection{Flash level}

\section{A regular IC (24 September 2012 02:02:32 UT)}

Figure 3 shows an example of a regular IC flash recorded by HyLMA during SOP1 Intensive Observation Period (IOP) IOP-06 on 24 September 2012. This flash was recorded within a mature convective cell. The lightning flash lasted for $800 \mathrm{~ms}$. It was composed of $2510 \mathrm{VHF}$ sources as reconstructed from at least seven HyLMA stations and $\chi^{2}<1$. For more information on the definition of the parameters associated to each LMA source the interested reader is referred to Thomas et al. (2004). The VHF sources were vertically distributed between 4 and $12 \mathrm{~km}$ (Fig. 3d). The IC flash was triggered at $8.5 \mathrm{~km}$ height (Fig. 3e). This IC flash exhibits a regular bi-level structure with long horizontal branches propagating at 6 and $11 \mathrm{~km}$ a.s.l. height (Fig. $3 \mathrm{~b}$ and c). The lower branches show weaker VHF sources than the upper branches and spread over a larger altitude range (Fig. 3f). The high (low) altitude horizontal branches correspond to negative (positive) leaders propagating through positive (negative) charge regions. As expected the upper channels, i.e., negative leaders, propagated faster as evidenced from the actual distances traveled by the negative leaders compared to the ones traveled by the positive leaders during the same temporal gap. During the development of the flash, most of the breakdown events are detected by HyLMA at the edge of the discharges previously ionized and consequently tend to widen the lower and upper channels away from the upward channel. HyLMA partially mapped one fast process at 02:02:33.557 that lasted for $3.5 \mathrm{~ms}$ and propagated over $25 \mathrm{~km}$ from the lower to the upper part of the flash (see the black lines in Fig. 3). Finally, none of the OLLSs re- ported that specific IC flash, while other IC flashes have been recorded by the OLLSs.

\section{A regular -CG (24 September 2012 01:43:17 UT)}

Figure 4 shows a compilation of records for a multi-stroke -CG flash as recorded not only by HyLMA and the different OLLSs, but also as sampled at close range $(25 \mathrm{~km})$ by the VFRS instruments and one of the SLAs. The flash lasted for more than $1.1 \mathrm{~s}$ and was composed of nine connections to the ground as deduced from the VFRS data analysis (Fig. 4e and f). HyLMA reconstructed 1464 VHF sources derived from at least seven HyLMA stations. The VHF sources were all located below $5.5 \mathrm{~km}$ height (Fig. 4d), and their 3-D distribution indicates that a negative charge region was located south of the ground strokes at an average altitude of $4.5 \mathrm{~km}$ height (Fig. 4a-c). Note that for the present -CG flash, HyLMA did not map entirely the downward stepped leaders down to the ground (Fig. $4 \mathrm{e}$ and $\mathrm{f}$ ).

The -CG flash was recorded by all OLLSs but ZEUS (Fig. 4g). ATDnet reported seven events, whereas EUCLID identified five strokes as negative ground connections and LINET categorized eight strokes as negative ground connections and one stroke as positive ground connection. Times of OLLS records obviously coincide with times of field record stroke measurements (in gray in Fig. $4 \mathrm{e}-\mathrm{g}$ ). The signal recorded by the SLA documented the changes induced by the successive ground connections and confirmed the negative polarity of the CG flash (Fig. 4f). The events recorded by the different OLLSs are mainly located close to each other except for one ATDnet stroke (Fig. 4a-c). Further investigations are underway to study both flash and stroke detection efficiencies and location accuracy of the OLLSs over the HyLMA domain using other coincident VFRS, SLA and HyLMA records. 

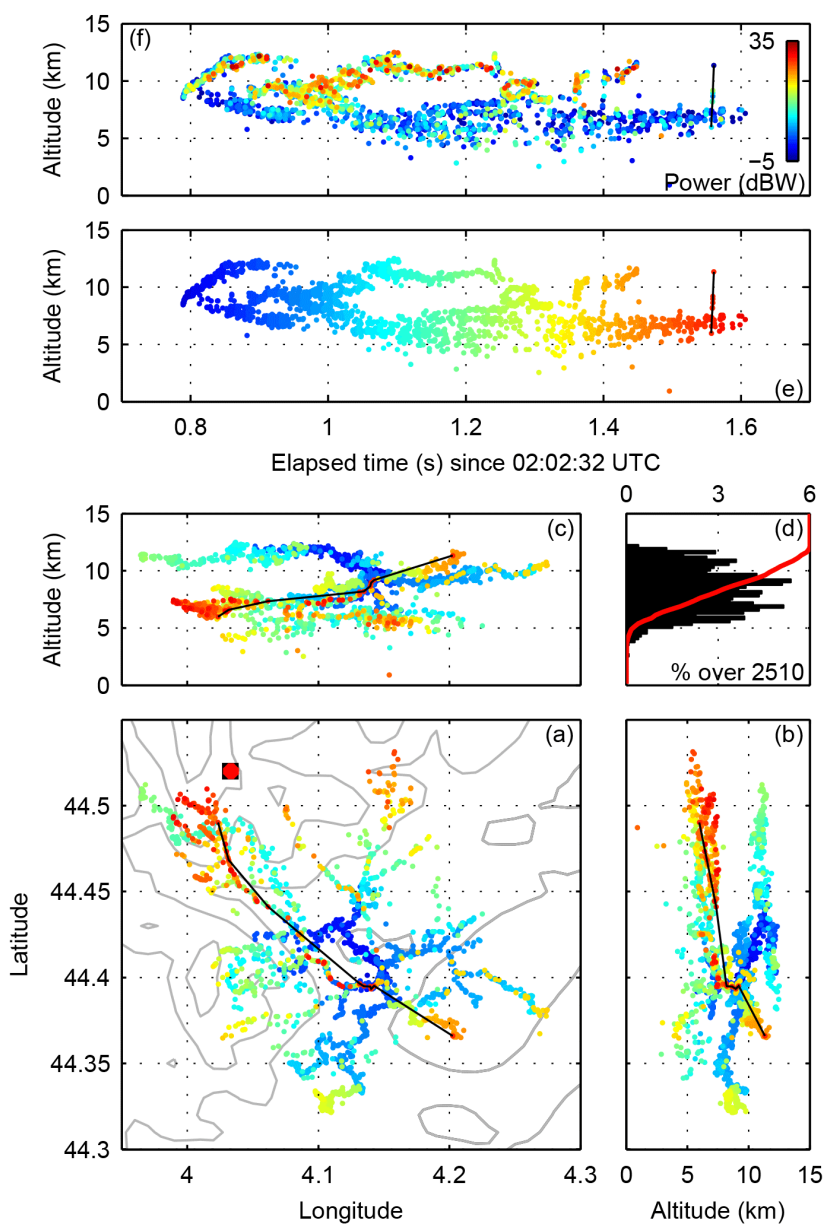

Figure 3. HyLMA records during a regular IC flash (24 September 2012, 02:02:32 UTC) with (a) ground projection of the lightning records with $200 \mathrm{~m}$ increment relief isolines; (b) latitude-altitude projection of the lightning records; (c) longitude-altitude projection of the lightning records; (d) $250 \mathrm{~m}$ increment histogram (bars) and cumulative distribution (red cure) of the VHF source altitude; (e) time-height series of VHF sources; and (f) amplitude-height series of VHF sources. The black lines join the successive VHF sources recorded during the $K$ change event at 02:02:33.557 UTC.

The same CG flash was also documented with the $5 \mathrm{~ms}$ camera as shown in Fig. 5, where the images recorded at the time of the ground connections identified from VFRS records are compiled. Times of the successive (single) frames are indicated in orange in Fig. 4g. The two first frames in Fig. 5 show clearly two channels connecting to the ground. The other frames show scattered light accompanying the successive return strokes but with the channel itself masked by a nearby hill, except the frame at 01:43:18.490 where much weaker optical signal was recorded (Fig. 5). ATDnet, EUCLID and LINET detected this specific stroke (Fig. 4g) as well as the field record sensor (Fig. 4e), but the change induced by this stroke had little impact as detected with the SLA (Fig. 4f). The first channel to ground was recorded with-
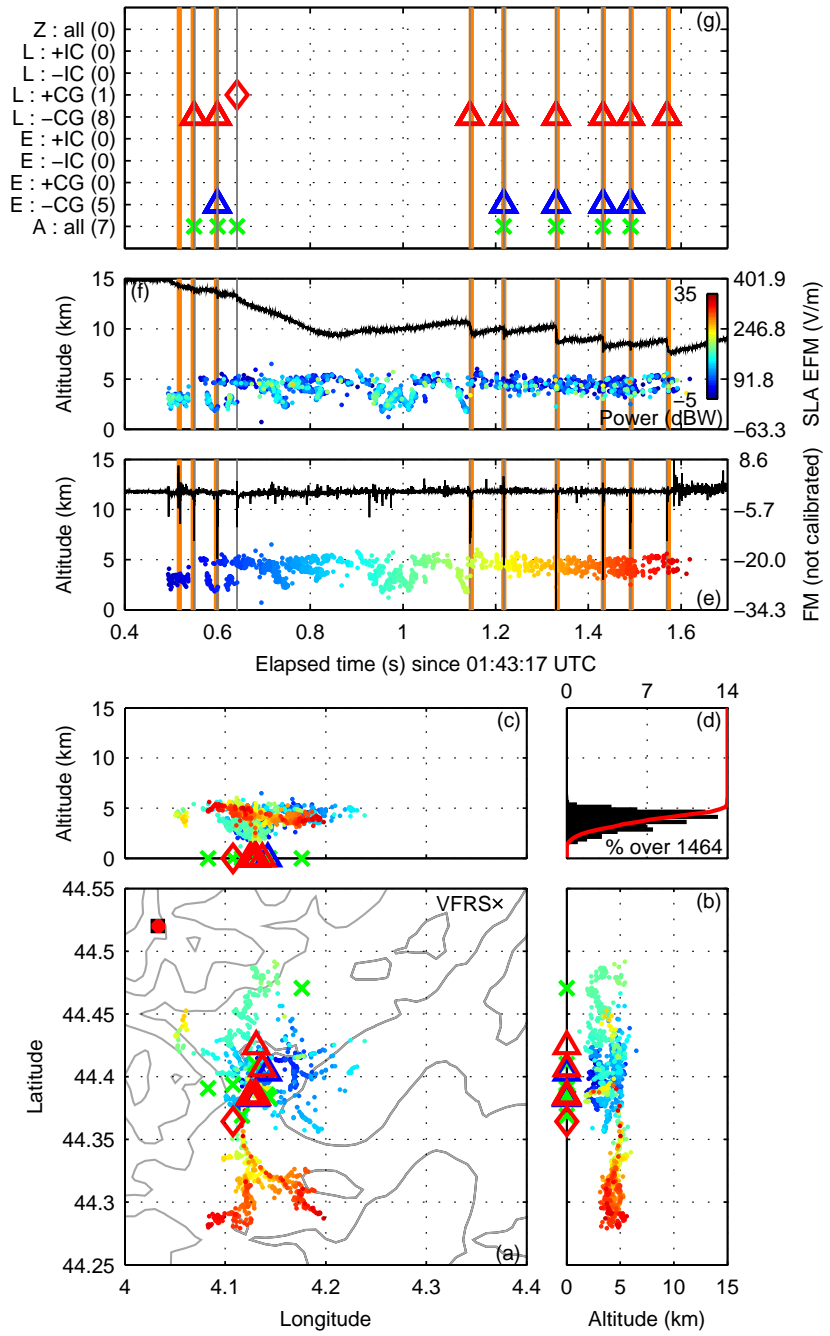

Figure 4. Records during a -CG flash with multiple ground connections (24 September 2012, 01:43:17 UTC) with (a) ground projection of the lightning records; (b) latitude-altitude projection of the lightning records; (c) longitude-altitude projection of the lightning records; (d) histogram (bars) and cumulative distribution (red cure) of the VHF source altitude; (e) time-height series of VHF sources and record of the Uzès SLA; (f) amplitude-height series of VHF sources and record of the VFRS electric field observations; and (g) records of OLLSs per instrument and type of detected events available only for EUCLID and LINET. The orange bars correspond to ground strokes as identified from VFRS records. The VFRS location is also indicated in (a). Gray lines indicate times of all OLLS reports. Records from ATDnet, EUCLID, LINET and ZEUS are plotted with green crosses, blue symbols, red symbols and black stars, respectively.

out any question by the video camera but was not located by any OLLS. Interestingly, a flash located $42 \mathrm{~km}$ away from VFRS and north to the -CG flash triggered around the time of the first ground connection, so the radiation might have interfered with the signal radiated by the first ground connection. Additionally, the noisy field record signal recorded at 


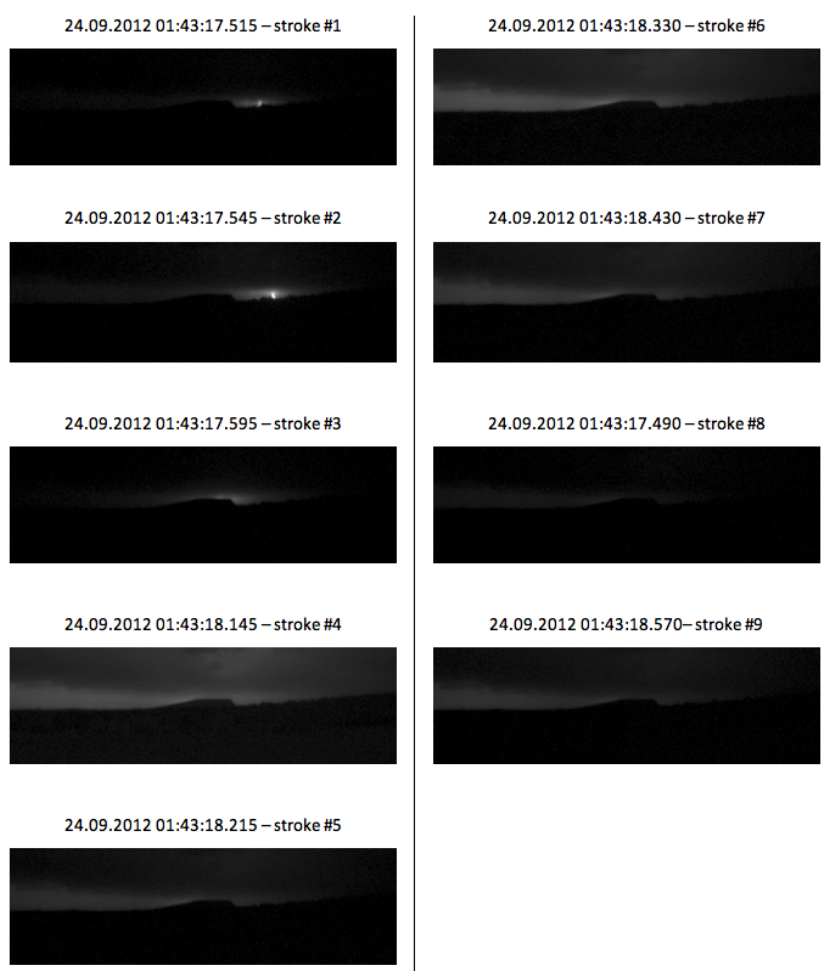

Figure 5. Enhanced VFRS $5 \mathrm{~ms}$ frames recorded during the nine ground strokes of the $-\mathrm{CG}$ flash presented in Fig. 4.

01:43:18.6 (Fig. 4e, elapsed time equal 1.6 s) emanated from the early stage of a $700 \mathrm{~ms}$ duration IC flash located $30 \mathrm{~km}$ north from the documented -CG flash.

Over the entire SOP1 campaign, several optical observations are available for other $-\mathrm{CG}$ flashes, $+\mathrm{CG}$ flashes and also IC flashes propagating along or below the cloud base. Even if the VFRS was mobile, it was often difficult to capture optical measurements either because of rain or presence of low-level clouds between the lightning flashes and the video camera. However, the recorded field record observations, with and without optical measurements, of the mobile instrumentations in conjunction with SLA records offer a rather unique ground truth to validate the OLLS records, quantify their detection efficiency and investigate in detail the flash processes that are recorded and located by the different OLLSs operated with short and long baselines.

\section{Examples of unusual lightning flashes}

The more HyLMA data are analyzed, the more we find lightning flashes that do not fit with either the bi-level structure of regular IC flashes or with the typical development of multistroke -CG flashes. In the following we present two examples of unusual lightning flashes. For instance, Fig. 6 presents the HyLMA and OLLS records for a specific type of flash called a bolt-from-the-blue (BFTB) type. In the present case, the flash (5 September 2012 17:51:20 UT) started like a reg-
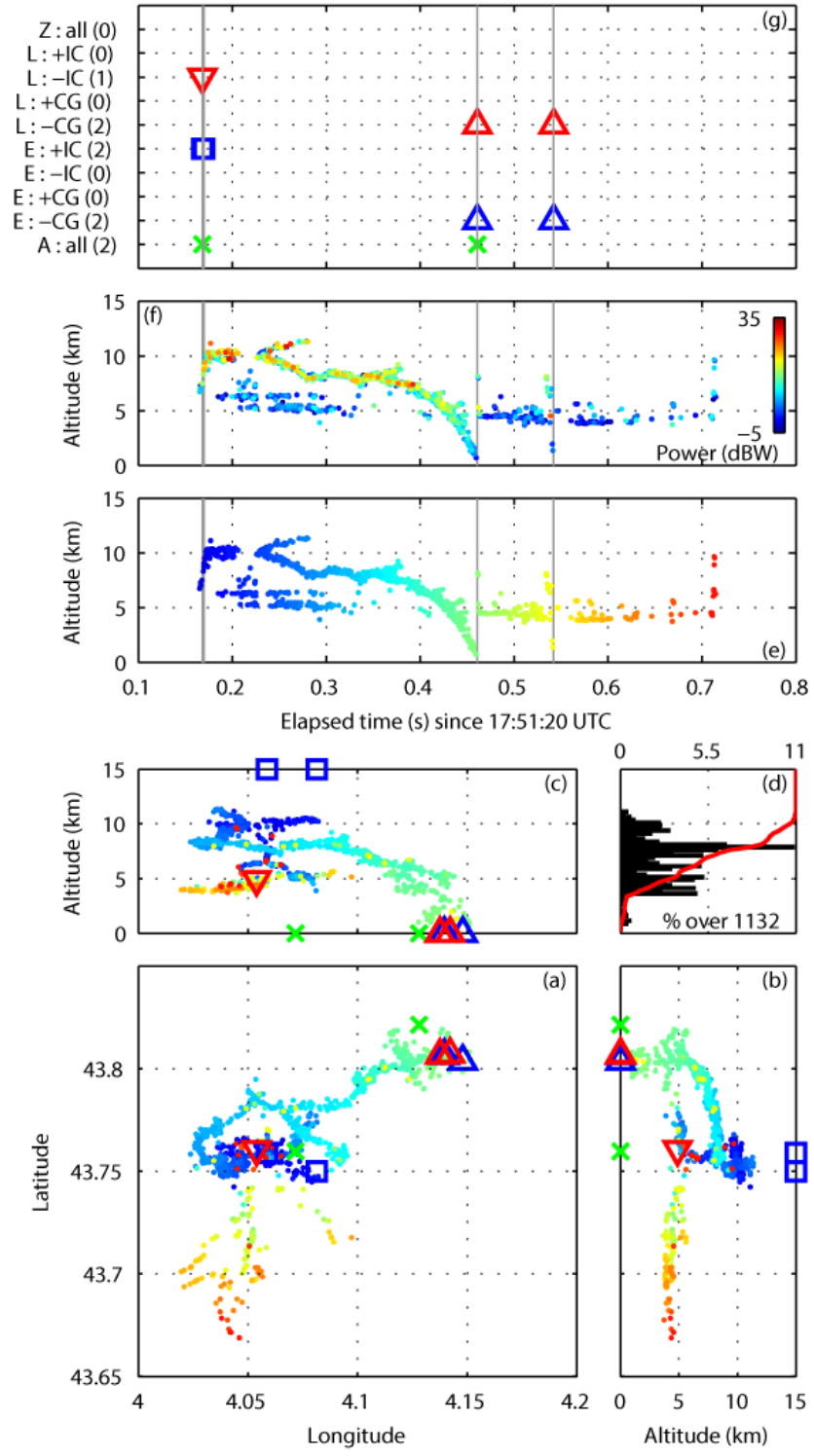

Figure 6. Concurrent lightning records during a bolt-from-the-blue flash recorded on 5 September 2012 at 17:51:20 UTC. See Fig. 4 for a description of each panel.

ular IC flash with an ignition at $6 \mathrm{~km}$ height. The upper discharge split in two parts $50 \mathrm{~ms}$ after its ignition, one progressing continuously upward while the other went downward, propagating at a constant altitude of $8 \mathrm{~km}$ during $50 \mathrm{~ms}$ before descending and eventually connecting to the ground. The altitude-latitude panel (Fig. 6b) clearly shows several branches of negative stepped leaders approaching the ground while the flash propagates to the ground.

EUCLID and LINET reported the first ground connection and a second ground strike (Fig. 6e and f). Additionally, EUCLID and LINET reported IC events a few milliseconds after the first VHF source (Fig. 6g). The locations of the IC events given by EUCLID and LINET are consistent with the 
HyLMA locations. LINET reported an IC event at an altitude of $5 \mathrm{~km}$, just above the negative charge region. This example demonstrates the capability of operational systems like EUCLID and LINET to detect IC components and potentially IC flashes.

The ZEUS network did not locate any event during that specific flash. ATDnet recorded the first ground connection but also the VLF radiation in the early beginning of the flash with a rather accurate location (Fig. 6a-c). This example, among others, confirms the capability of sferic-detecting networks to locate some IC components, as Lagouvardos et al. (2009) already reported with ZEUS and LINET. The HyMeX SOP1 data offer a unique opportunity to not only study the CG and IC detection efficiencies as well as location accuracy, but also to investigate the discharge properties with a signal strong and well pronounced enough to be detected and located by long range VLF detection systems. Over a total of 124 flashes, 11 BFTB flashes were recorded during the entire life cycle of the isolated storm on 5 September 2012, with negative downward stepped leaders propagating from the upper positive charge region to the ground. Other BFTB flashes have been identified in the HyLMA data set analyzed so far, such as the ones observed during the IOP-06 case on 24 September 2012 (not shown).

Figure 7 presents an example of a complex flash recorded on 30 August 2012 (04:35:00 UTC) before the beginning of SOP1. The VHF radiations were recorded over more than $5 \mathrm{~s}$ and the lightning flash propagated from the northwest to the southeast over a large domain (>120 km long; Fig. 7ac). The temporal and spatial evolution of the successive discharges mapped by HyLMA reveals that the continuous VHF signal emanated from a single but extensive lightning flash. The flash mainly occurred on the eastern side of the HyLMA coverage area. Comparison with radar observations indicated that the flash propagated in a stratiform region (not shown). The spatial distribution of the VHF sources suggests the existence of multiple charge regions in the parent cloud at different altitudes (Fig. $7 \mathrm{~b}$ and c). Another long-lasting flash occurred in the same area 4(17) s before (after) the occurrence of the studied flash. Flashes of 2 to $3 \mathrm{~s}$ duration were also recorded between 04:00 and 05:00 UTC mostly in the northwestern part of the storm complex. Between 04:30 and 04:40 UTC, 44 flashes were recorded over the domain of interest; all but the one shown in Fig. 7 occurred in the northwestern electrical cell centered at $44.5^{\circ} \mathrm{N}$ and $5^{\circ} \mathrm{E}$.

All OLLSs reported space and time consistent observations relative to HyLMA records. ATDnet reported four fixes, EUCLID 14 events including eight negative ground strokes and one positive ground stroke, LINET 14 events, all identified as ground strokes as no altitude information was available, and ZEUS seven fixes. A single flash identified by HyLMA is actually seen as multiple flashes by the OLLSs with the algorithms used to combine strokes/fixes into flashes. This unusual flash example demonstrates the relevance and the usefulness of VHF mapping to characterize
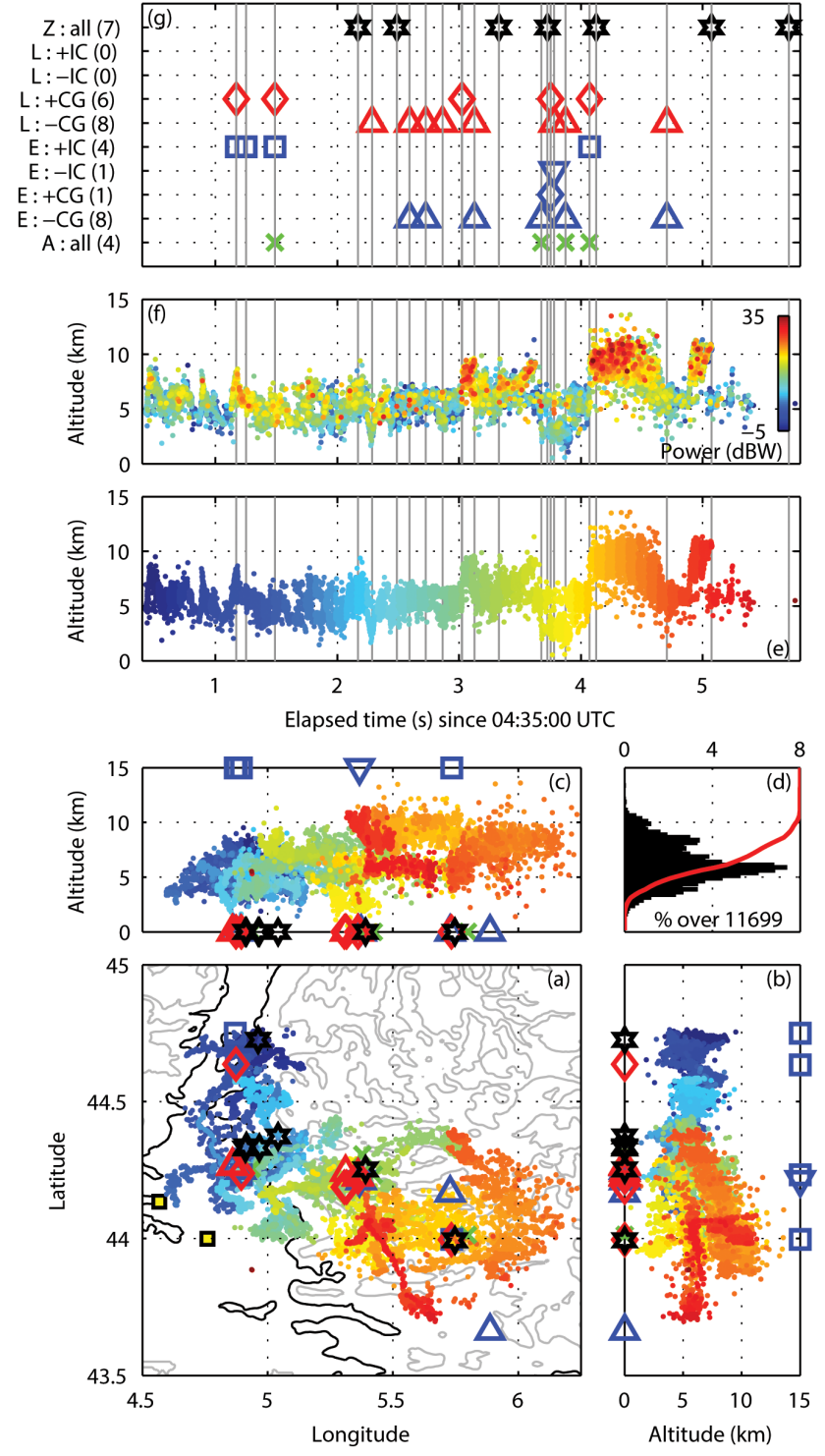

Figure 7. LMA and OLLS records during a hybrid long-lasting flash. See Fig. 4 for a description of each panel. The relief is plotted with $500 \mathrm{~m}$ isolines. The black isoline corresponds to $200 \mathrm{~m}$ height.

the full 3-D spatial extension of the lightning flashes. Additionally, some of the events detected by one OLLS are also detected by one or more other OLLSs, while sometimes an event is reported by a single OLLS only. This was also observed during the analysis of the lightning data for the 68 September 2010 storm but not discussed in Lagouvardos et al. (2013). Such discrepancies are explained by the differences between the four OLLSs in terms of technology, range and amplitude sensibility, detection efficiency and location algorithms. For the studied flash, coincident OLLS strokes are observed with a time difference from 60 to $130 \mu$ s between long-range and short-range OLLSs and around $20 \mu \mathrm{s}$ between EUCLID and LINET. 


\section{Concurrent VHF and acoustic measurements}

Acoustic and infrasonic measurements were performed during HyMeX SOP1 as detailed in Sect. 3.2.3. Figure 8 presents an example of concurrent records during $2.5 \mathrm{~min}$ of lightning activity sensed on 24 September 2012. During that period, HyLMA detected seven lightning flashes (with one composed of a few VHF sources) in the studied area (Fig. 8a and e), all inducing a moderate to significant change on the SLA signal (Fig. 8g). ATDnet sensed all flashes except the one composed of a few VHF sources at $T=48 \mathrm{~s}$ (Fig. 8g). EUCLID, LINET and ZEUS recorded all but two flashes including the one composed of a few VHF sources; the second flash was not the same for these three OLLSs. ZEUS erroneously located additional flashes in the domain of interest. Among the seven flashes, three were connected to the ground with a negative polarity (Fig. $8 \mathrm{~g}$ ). The lightning activity was located about $20 \mathrm{~km}$ away from the acoustic sensors marked with a red diamond in Fig. 8a. The time evolution of the pressure difference (Fig. 8e) traces two acoustic events of duration greater than $20 \mathrm{~s}$. The first event, between $T=40 \mathrm{~s}$ and $T=70 \mathrm{~s}$ is related to the first IC flash recorded during the first seconds of the studied period. The second acoustic event, starting at $T=105 \mathrm{~s}$, comes from the two flashes (one $-\mathrm{CG}$ and one IC) recorded between $T=60 \mathrm{~s}$ and $T=70 \mathrm{~s}$. The propagation of sound waves in the atmosphere and the properties of the atmosphere along the acoustic path to the acoustic sensors are at the origin of the delay between the recording of the electromagnetic signal and the recording of the acoustic signal. For the first acoustic event, the acoustic spectrogram (Fig. 8f) reveals a series of three acoustic bursts while for the second acoustic event, the spectrogram shows a less powerful signal. A signal of $0.2 \mathrm{~Pa}$ (absolute value) received by the sensors $20 \mathrm{~km}$ away from the storm is in the amplitude range of acoustical signals usually recorded. Based on the unique data set collected during the SOP1, several studies have been performed to relate the acoustic signal and its spectral and temporal properties to the original lightning flash type and properties.

\subsubsection{Examples of SOP1 daily lightning activity recorded by HyLMA}

The previous sections showed a series of concurrent records at the flash scale. Here we discuss some storms recorded during the SOP1. Although lightning activity recorded during the June-August period is not discussed here, it is worth mentioning that different types of storms were fully recorded during the entire HyLMA operation. As an example, Fig. 9 shows daily lightning maps as produced only from HyLMA data with, for each considered day, the $10 \mathrm{~min}$ VHF source rate reconstructed from at least seven LMA stations over the HyLMA coverage area in panel a, the geographical distribution of the lightning activity (the grayscale is time related) with an overlay of the $1 \mathrm{~h}$ VHF source density (per
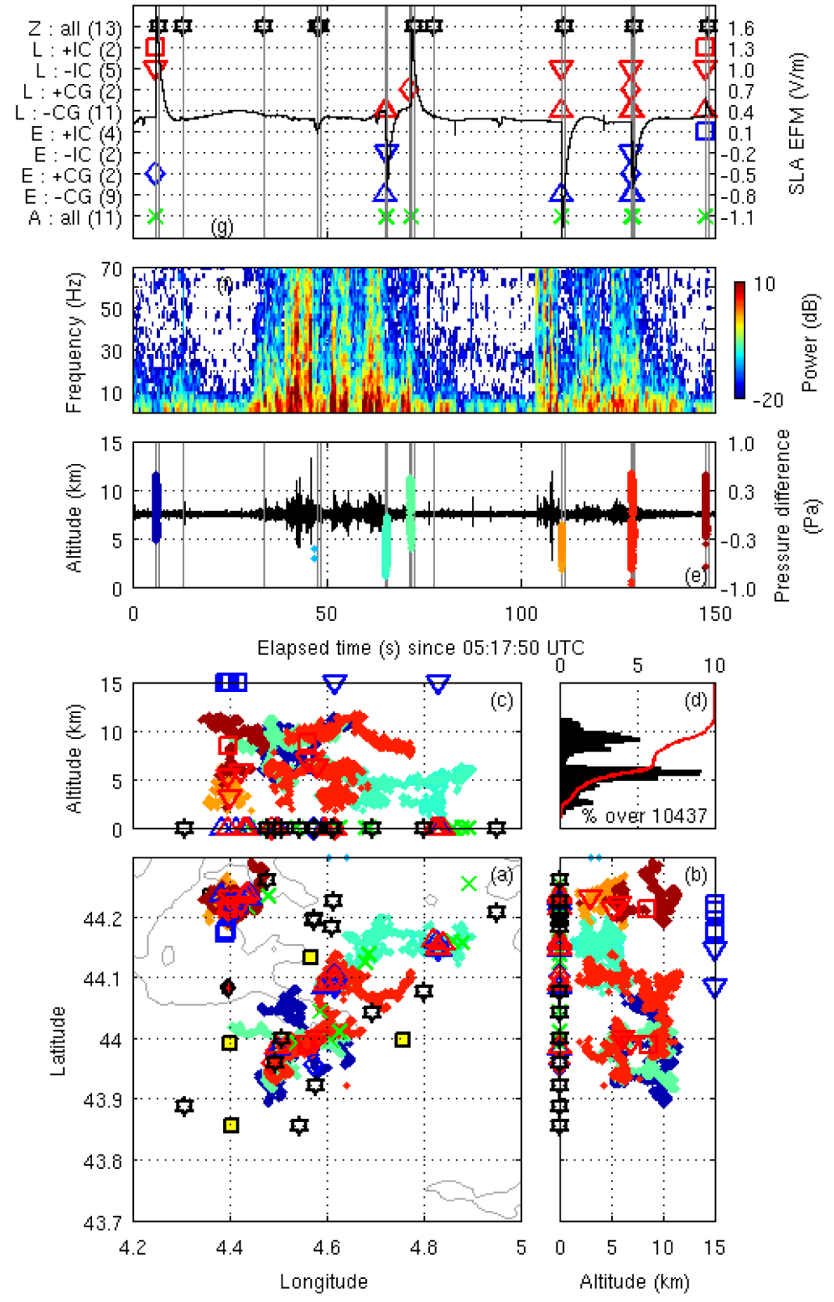

Figure 8. Coincident observations recorded between 05:17:50 and 05:20:20 UTC on 24 September 2012 with (a) ground projection of the lightning records; (b) latitude-altitude projection of the lightning records; (c) longitude-altitude projection of the lightning records; (d) $250 \mathrm{~m}$ increment histogram (bars) and cumulative distribution (red cure) of the VHF source altitude; (e) time-height series of VHF sources and pressure difference measured at the MPA location; (f) time series of the acoustic spectrum as recorded at MPA location; and (g) records of OLLSs per instrument with the time series of the Uzès SLA record.

$\left.0.025^{\circ} \times 0.025^{\circ}\right)$ at one specific hour in panel $\mathrm{b}$, and the vertical distribution of the VHF sources (per $0.025^{\circ} \times 200 \mathrm{~m}$ ) computed during the hour indicated at the top of the figure in panel c. As already mentioned, different types of convective systems were recorded during the operation of HyLMA, ranging from gentle isolated thunderstorms to organized and highly electrical convective lines between June 2012 and November 2012.

Figure 9A shows the lightning activity recorded during IOP-01 (11 September 2012) associated with scattered deep convection developing in early afternoon (Fig. 9A.a) over 
southeastern Massif Central and due to a convergence between a slow southeasterly flow from the Mediterranean Sea and a westerly flow from the Atlantic. The convection remained isolated and mainly confined to mountainous areas, with some cells reaching the foothills in late afternoon due to the westerly mid-level flow (Fig. 9A.b). The French F20 research aircraft, along with the airborne $95 \mathrm{GHz}$ Doppler cloud radar RASTA (RAdar SysTem Airborne) and in situ microphysics probes, sampled the anvils of the closest convective cells to the HyLMA stations. The rainfall accumulation ranged from 5 to $10 \mathrm{~mm}$ in $24 \mathrm{~h}$ and reached local levels of up to $30-40 \mathrm{~mm}$ in Ardèche. This example shows typical observations collected with HyLMA during scattered convection over the domain of interest, definitively demonstrating that the records of HyLMA as well as the records of OLLSs offer the possibility of a radar-like tracking of storm motions.

Figure 9B shows the HyLMA records during IOP-06 (24 September 2012). An intense and fast-moving convective line crossed the CV domain during the early morning, Liguria-Tuscany by mid-day and northeastern Italy in the evening, with an amount of rainfall observed of $100 \mathrm{~mm}$ in $24 \mathrm{~h}$ over southeastern France, rainfall intensity up to 50$60 \mathrm{~mm} \mathrm{~h}^{-1}$ and wind gusts up to $90-100 \mathrm{~km} \mathrm{~h}^{-1}$ locally. The storm activity started in the evening of 23 September on the west side of the HyLMA network and moved to the east with successive electrical cells developing and merging. Figure 9B.b and c show one of the highest density of VHF sources recorded during the entire period of HyLMA operation. Between 02:00 and 03:00 UTC, the lightning activity was more or less distributed along a north-south direction but then extended further north to the HyLMA network (Fig. 9B.b). Focusing on the electrical cells located in the vicinity of the LMA network, the lightning activity was located east of strong updrafts retrieved from the radar data (see Fig. 8 in Bousquet et al., 2014), with the deepest electrified convective cell reaching up to $13 \mathrm{~km}$ height. Many different PEACH instruments documented the lightning activity of this storm as shown in Figs. 3, 4 and 8. The VFRS was operated from the Aubenas airfield $\left(44.538^{\circ} \mathrm{N}, 4.371^{\circ} \mathrm{E}\right)$ from the early hours of the storm activity to mid-morning. Some storm cells were also documented with the airborne RASTA radar and in situ microphysics probes on board the F20 and by different precipitation research radars located in the northern part of the HyLMA coverage area.

Figure $9 \mathrm{C}$ shows the total lightning activity sensed during IOP-07a (26 September 2012). The first convective system appears early in the morning over the HyLMA because of a warm, unstable and convergent air mass that merges with a frontal system progressing eastwards during the afternoon. This event brings more than $100 \mathrm{~mm}$ in $24 \mathrm{~h}$ over the CV region. Additionally, the city of Nice on the Riviera Coast was flooded in the evening (Fig. 9C.b). The VFRS operated from Valence $\left(44.992^{\circ} \mathrm{N} 4.887^{\circ} \mathrm{E}\right)$ during the first part of the day and then moved to Mont Ventoux $\left(44.171^{\circ} \mathrm{N}, 5.202^{\circ} \mathrm{E}\right)$.
During the morning observations, most CG flashes recorded with VFRS instruments in the northern part of the convective complex were of positive polarity, while the CG flashes in the afternoon were mostly negative.

Figure 9D shows the HyLMA records for 29 September 2012 (IOP-08). This system moved from Spain where heavy precipitation was recorded on the northeasterly flank of Spain with casualties and significant damages. Figure 9D.b shows an extensive area of coverage by the HyLMA in its southeastern sector with more pronounced altitude errors for very distant flashes. The case is interesting as it moved from sea to land (Fig. 9D.b); it allows the investigation of contrasting lightning properties over sea and over land as well as the documentation of the transition from sea to land. VFRS observations were collected for lightning flashes along the Riviera.

Figure 9E shows the lightning activity of IOP-13 (14 October 2012) where Nice airport was closed at the end of the day because of strong vertical shear. A tornado (EF1) was observed in the vicinity of Marseille between 14:00 and 15:00 UTC. The analysis of the lightning activity of the tornado cloud revealed the occurrence of a convective surge with a sudden increase of the flash rate and an upward shift of the flash triggering altitude (not shown). Analyses combining HyLMA, OLLSs and operational radar records are underway to evaluate the benefit of lightning detection in terms of information precursors related to this tornado. Additionally, the French F20 aircraft sampled some electrified clouds and later (17:00-20:00 UTC) performed a survey of precipitating systems over Provence/Côte d'Azur (French Riviera), which offers the possibility to study in situ microphysics, vertical structure of the clouds and lightning activity.

Finally, Fig. 9F shows the observed lightning activity during IOP-16a (26 October 2012). A system first affected the Hérault and Gard departments in the morning but a second more intense system developed in the southeast of France in the afternoon with two casualties in Toulon. Rain accumulation reached up to $170 \mathrm{~mm}$ in $24 \mathrm{~h}$ in the CV domain. The F20 aircraft flew between 06:00 and 09:30 UTC in the complex located at $43^{\circ} \mathrm{N}, 4^{\circ} \mathrm{E}$ (Fig. 9F.b). A second F20 flight sampled the electrically active storms shown in Fig. 9F.b $\left(43.2^{\circ} \mathrm{N}, 6^{\circ} \mathrm{E} ; 43.2^{\circ} \mathrm{N}, 3^{\circ} \mathrm{E}\right)$. VFRS observations were performed at the end of the day about $50 \mathrm{~km}$ east of the HyLMA network for a series of mainly -CG flashes. Between 20:30 and 20:40 UTC the lightning activity sensed in the vicinity of the MBA/MPA network was rather weak (i.e., 24 flashes in $10 \mathrm{~min}$ ), so one-to-one correlations between RF HyLMA and EUCLID records and non-noisy acoustics signals from the same flashes are currently being studied (not shown).

\section{Prospects}

The present article summarizes only a small number of events observed with different PEACH instruments during 
(a)
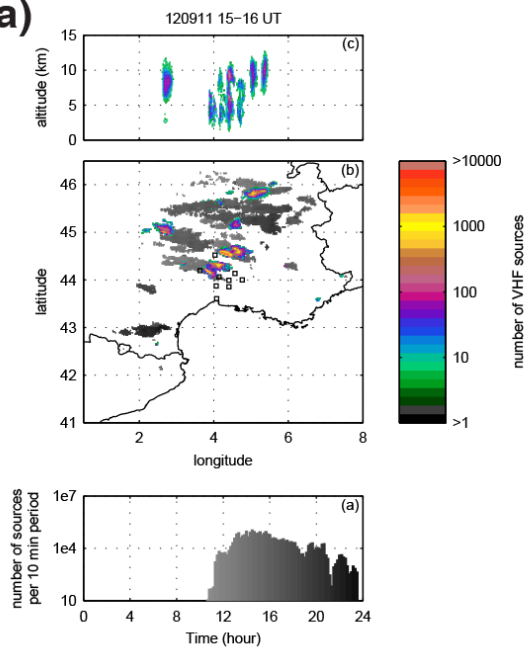

(c)
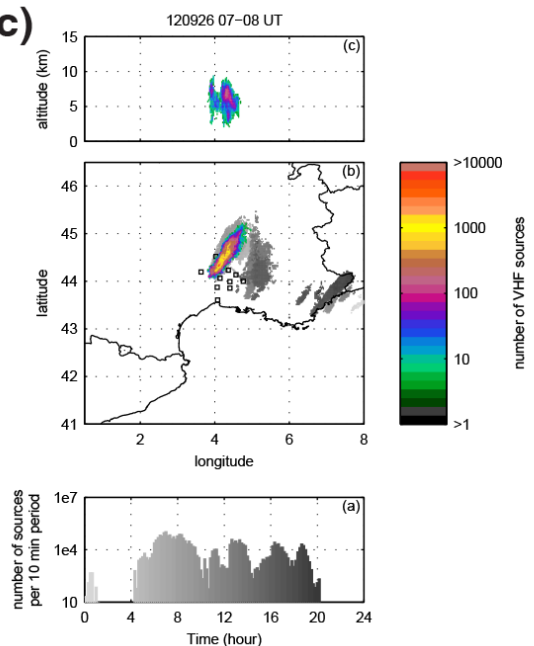

(e)
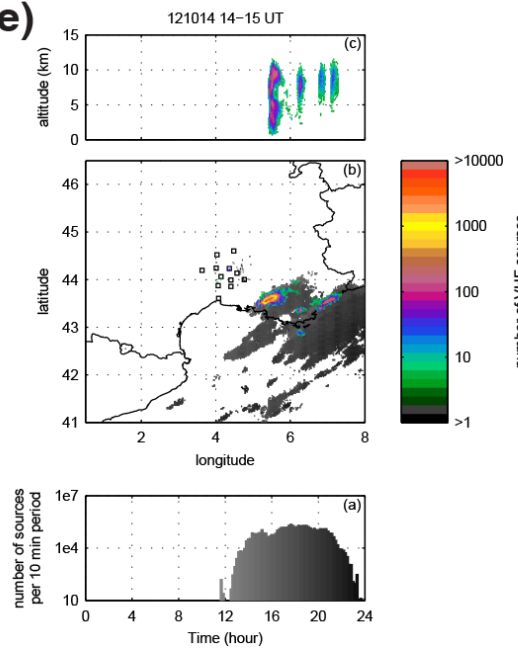

(b)
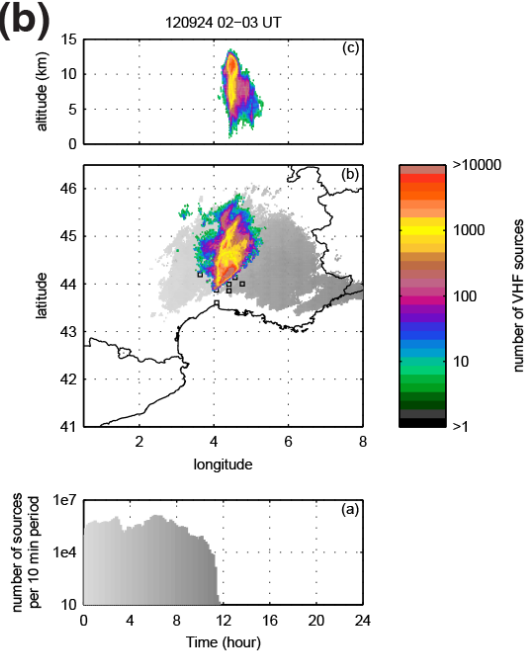

(d)
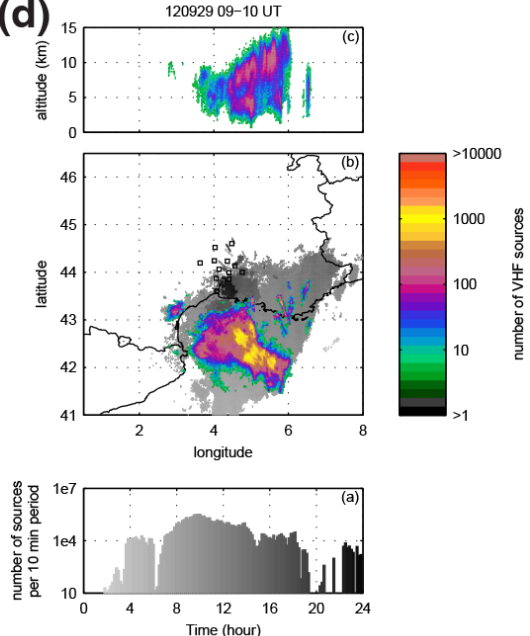

(f)
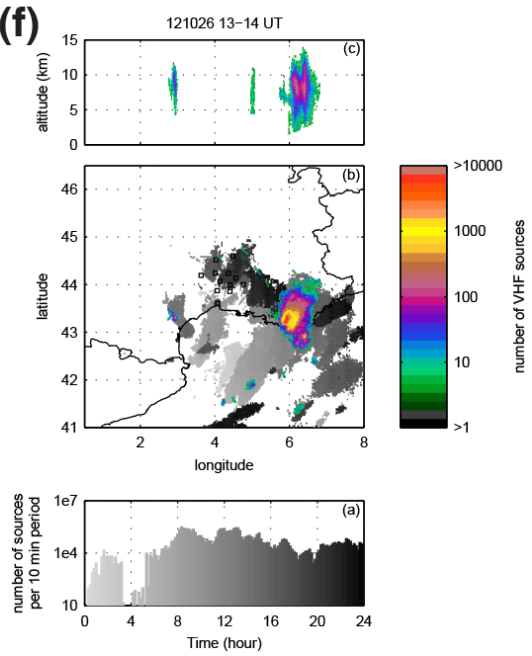

Figure 9. Total lightning activity recorded at different dates with HyLMA. (a) HyLMA VHF source rate per 10 min period (plotted in decimal logarithmic scale); (b) ground projection of the HyLMA sources during 24 h (in gray, from 00:00 to 23:59 UTC) and density of HyLMA VHF sources during $1 \mathrm{~h}$ computed per $0.025^{\circ} \times 0.025^{\circ}$ grid (in color); (c) vertical distribution of the HyLMA VHF sources for the same $1 \mathrm{~h}$ period (and indicated at the top of the panel) per $0.025^{\circ} \times 200 \mathrm{~m}$ grid. 
HyMeX SOP1. This rather unique and comprehensive lightning data set collected during the SOP1 will serve to investigate the properties of individual lightning flashes but also to probe objectively, for the first time, the performances of European OLLSs in southeastern France and close to the Mediterranean Sea. This task will help to refine our current knowledge on what European OLLSs actually record and more specifically which intra-cloud processes are detected and located. The investigation should eventually provide new insights on the potential of IC detection from European OLLSs for operational storm tracking and monitoring over the entire Mediterranean basin.

Several analyses are already underway to investigate the properties of the lightning activity from the flash scale to the regional scale in relation to cloud and atmospheric properties as derived from satellite imagery, operational/research ground-based and airborne radars, rain gauges and in situ microphysical probes. The analyses focus not only on HyMeX SOP1 priority cases (Ducrocq et al., 2014) but also on nonSOP1 events as HyLMA data cover June 2012 to the end of November 2012. The analysis will eventually provide key lightning-related indexes to describe the electrical nature of thunderstorms in southeastern France and which will be used in multi-disciplinary studies carried out within HyMeX. The combination of HyLMA and OLLS records will provide a set of basic products - e.g., flash rate, flash type, flash properties and flash density - to populate the HyMeX database.

The HyMeX case studies are not only observationally oriented but are also intended to provide material for verification and validation of kilometer-scale electrified cloud simulations (e.g., Pinty et al., 2013). Indeed, successful simulations are already performed and comparisons of simulated and observed parameters - e.g., vertical distribution of the charge regions, flash location, flash rate and flash extension - are already showing promising results. The HyLMA data should then help to identify objectively which non-inductive charging process treatment ("Takahashi" versus "Saunders") leads to the best simulation results.

An objective debriefing of SOP1 preparation, operation and data analysis will be performed in the near future to identify the successes and the failures. This will help us to refine the preparation of a dedicated atmospheric electricity field campaign in early autumn 2016 over Corsica because a permanent LMA was established there in May 2014 for a minimum of 5 years. Another region of interest is the eastern Mediterranean Sea during autumn, when electrical activity takes place over the sea but ceases when the thunderclouds are landing.

Finally, the different activities performed around the PEACH project have already helped us gain expertise not only for field deployment and operations but also in terms of data analysis methodologies, realistic lightning and cloud simulations and application of lightning detection for very short-range forecasts in preparation for the EUMETSAT Me- teosat Third Generation Lightning Imager (launch scheduled early 2019).

Acknowledgements. This project was sponsored by grants MISTRALS/HyMeX and ANR-11-BS56-0005 IODA-MED. LEFE-IDAO, Université de Toulouse and the GOES-R visiting program also supported the PEACH project during its preparation and the field campaign. The Greek contribution to PEACH objectives is partially funded by the TALOS project, in the frame of "ARISTEIA II", by the Greek General Secretariat for Research and Technology. We are grateful to R. Blakeslee and NASA for lending the MSFC LMA during the SOP1. We would like to thank the team of the local Météo-France weather office in Nîmes for its strong support during the site survey, deployment, operation and dismantlement of the instruments and for letting us deploy four of the HyLMA stations on Météo-France land. We also thank Mr. and Ms. Imbert (Cadignac HyLMA site), Mr. Rey and the Méjannes-le-Clap City Council (Méjannes-le-Clap HyLMA site), Mr. Comte (Vic-le-Fesq HyLMA site), Mr. and Ms. Bazalgette (Mont Aigoual HyLMA site), Mr. Vincent (Mont Perier HyLMA site), Mr. Chaussedent (Mirabel HyLMA site), Mr. Fourdrigniez (CCI Alès Deaux airfield HyLMA site) and Mr. Garrouste (CNRM-GAME, responsible for the Candillargues HyMeX supersite; Candillargues HyLMA site) for hosting a HyLMA station. We also thank Mr. Reboulet (Mayor of La Bruguière) for allowing the deployment of one SLA and the MBA/MPA package on his property. We also thank Mr. Cerpedes (La Grande-Combe Technical Manager) for letting us deploy the second SLA on La Grande-Combe airfield. We are also grateful to the different weather forecasters and the HyMeX operation direction for the support to the VFRS. We thank Georg Pistotnik from the European Severe Storm Laboratory (ESSL) for providing additional special forecasts in preparation and during several VFRS observation trips. We thank Patrice Blanchet (ONERA) and Philippe Lalande (ONERA) for lending us their fast video camera that was operated at some of the VFRS sites. We also thank Brice Boudevilain (LTHE) and Olivier Bousquet (Météo-France) for providing contacts for the deployment of the four most remote HyLMA stations. Finally we would like to thank D. Poelman and the second anonymous reviewer for their careful reading of the manuscript and their constructive suggestions.

Edited by: M. Nicolls

\section{References}

Adamo, C.: On the use of lightning measurements for the microphysical analysis and characterization of intense precipitation events over the Mediterranean area, PhD dissertation, Univ. of Ferrara, Ferrara, Italy, 2004.

Altaratz, O., Reisin, T., and Levin, Z.: Simulation of the Electrification of Winter Thunderclouds using the 3-dimensional RAMS Model: single cloud simulations, J. Geophys. Res, 110, 1-12, D20205, 2005.

Arechiga, R. O., Johnson, J. B., Edens, H. E., Thomas, R. J., and Rison, W.: Acoustic localization of triggered lightning, J. Geophys. Res., 116, D09103, doi:10.1029/2010JD015248, 2011. 
Barthe, C. and Barth, M. C.: Evaluation of a new lightningproduced $\mathrm{NO}_{\mathrm{x}}$ parameterization for cloud resolving models and its associated uncertainties, Atmos. Chem. Phys., 8, 4691-4710, doi:10.5194/acp-8-4691-2008, 2008.

Barthe, C. and Pinty, J.-P.: Simulation of electrified storms with comparison of the charge structure and lightning efficiency, J. Geophys. Res., 112, D19204, doi:10.1029/2006JD008241, 2007a.

Barthe, C. and Pinty, J.-P.: Simulation of a supercellular storm using a three-dimensional mesoscale model with an explicit lightning flash scheme, J. Geophys. Res., 112, D06210, doi:10.1029/2006JD007484, 2007b.

Barthe, C., Molinié, G., and Pinty, J.-P.: Description and first results of an explicit electrical scheme in a 3D cloud resolving model, Atmos. Res., 76, 95-113, 2005.

Barthe, C., Pinty, J.-P., and Mari, C.: Lightning-produced $\mathrm{NO}_{\mathrm{x}}$ in an explicit electrical scheme tested in a Stratosphere-Troposphere Experiment: Radiation, Aerosols, and Ozone case study, J. Geophys. Res., 112, D04302, doi:10.1029/2006JD007402, 2007.

Barthe, C., Chong, M., Pinty, J.-P., Bovalo, C., and Escobar, J.: CELLS v1.0: updated and parallelized version of an electrical scheme to simulate multiple electrified clouds and flashes over large domains, Geosci. Model Dev., 5, 167-184, doi:10.5194/gmd-5-167-2012, 2012.

Beard, K. V.: Terminal velocity and shape of cloud and precipitation drops aloft, J. Atmos. Sci., 33, 851-864, 1976.

Betz, H.-D., Schmidt, K., and Oettinger, W. P.: LINET - An International VLF/LF Lightning Detection Network in Europe, in: Lightning: Principles, Instruments and Applications, edited by: Betz, H.-D., Schumann, U., and Laroche, P., Ch. 5, Dordrecht (NL), Springer, 2008.

Betz, H.-D., Schmidt, K., Laroche, P., Blanchet, P., Oettinger, W. P., Defer, E., Dziewit, Z., and Konarski, J.: LINET - an international lightning detection network in Europe, Atmos. Res., 91, 564573, 2009.

Blanc, E., Farges, T., Le Pichon, A., and Heinrich, P.: Ten year observations of gravity waves from thunderstorms in western Africa, J. Geophys. Res.-Atmos., 119, 6409-6418, doi:10.1002/2013JD020499, 2014.

Bousquet, O., Berne, A., Delanoe, J., Dufournet, Y., Gourley, J. J., Van-Baelen, J., Augros, C., Besson, L., Boudevillain, B., Caumont, O., Defer, E., Grazioli, J., Jorgensen, D. J., Kirstetter, P.E., Ribaud, J.-F., Beck, J., Delrieu, G., Ducrocq, V., Scipion, D., Schwarzenboeck, A., and Zwiebel, J.: Multiple-Frequency Radar Observations Collected In Southern France During HyMeX SOP-1, B. Am. Meteorol. Soc., online first, doi:10.1175/BAMSD-13-00076.1, 2014.

Chauzy, S. and Soula, S.: General interpretation of surface electric field variations between lightning flashes, J. Geophys. Res., 92, 5676-5684, 1987.

Christian, H. J., Blakeslee, R. J., Boccippio, D. J., Boeck, W. L., Buechler, D. E., Driscoll, K. T., Goodman, S. J., Hall, J. M., Koshak, W. J., Mach, D. M., and Stewart, M. F.: Global frequency and distribution of lightning as observed from space by the Optical Transient Detector, J. Geophys. Res., 108, 4005, doi:10.1029/2002JD002347, 2003.

Coquillat, S. and Chauzy, S.: Computed conditions of corona emission from raindrops, Corona emission from raindrops in strong electric fields as a possible discharge initiation: comparison be- tween horizontal and vertical field configurations, J. Geophys. Res., 99, 16897-16905, 1994.

Coquillat, S., Combal, B., and Chauzy, S.: Corona emission from raindrops in strong electric fields as a possible discharge initiation: comparison between horizontal and vertical field configurations, J. Geophys. Res., 108, 4205, doi:10.1029/2002JD002714, 2003.

Crabb, J. A. and Latham, J.: Corona from colliding drops as a possible mechanism for the triggering of lightning, Q. J. Roy. Meteor. Soc., 100, 191-202, 1974.

Cummins, K., Murphy, M., Bardo, E., Hiscox, W., Pyle, R., and Pifer, A.: A Combined TOA-MDF Technology Upgrade of the U.S. National Lightning Detection Network, J. Geophys. Res., 103, 9035-9044, 1998.

Defer, E. and Laroche, P.: Observation and Interpretation of Lightning Flashes with Electromagnetic Lightning Mapper, in: Lightning: Principles, Instruments and Applications, edited by: Betz, H.-D., Schumann, U., and Laroche, P., Ch. 5, Dordrecht (NL), Springer, 2009.

Defer, E., Blanchet, P., Théry, C., Laroche, P., Dye, J., Venticinque, M., and Cummins, K.: Lightning activity for the July 10, 1996, storm during the Stratosphere-Troposphere Experiment: Radiation, Aerosol, and Ozone-A (STERAO-A) experiment, J. Geophys. Res., 106, 10151-10172, 2001.

Defer, E., Lagouvardos, K., and Kotroni, V.: Lightning activity in Europe as sensed by long range NOA-ZEUS and UK Met Office ATD VLF lightning systems and NASA TRMM-LIS sensor, Geophys. Res. Abstr., EGU05-A-03026, EGU General Assembly 2005, Vienna, Austria, 2005.

Ducrocq, V., Braud, I., Davolio, S., Ferretti, R., Flamant, C., Jansa, A., Kalthoff, N., Richard, E., Taupier-Letage, I., Ayral, P.-A., Belamari, S., Berne, A., Borga, M., Boudevillain, B., Bock, O., Boichard, J.-L., Bouin, M.-N., Bousquet, O., Bouvier, C., Chiggiato, J., Cimini, D., Corsmeier, U., Coppola, L., Cocquerez, P., Defer, E., Delanoë, J., Di Girolamo, P., Doerenbecher, A., Drobinski, P., Dufournet, Y., Fourrié, N., Gourley, J. J., Labatut, L., Lambert, D., Le Coz, J., Marzano, F. S., Molinié, G., Montani, A., Nord, G., Nuret, M., Ramage, K., Rison, W., Roussot, O., Said, F., Schwarzenboeck, A., Testor, P., Van Baelen, J., Vincendon, B., Aran, M., and Tamayo, J.: HyMeX-SOP11: The Field Campaign Dedicated to Heavy Precipitation and Flash Flooding in the Northwestern Mediterranean, B. Am. Meteorol. Soc., 95, 1083-1100, doi:10.1175/BAMS-D-12-00244.1, 2014.

Duffourg, F. and Ducrocq, V.: Origin of the moisture feeding the Heavy Precipitating Systems over Southeastern France, Nat. Hazards Earth Syst. Sci., 11, 1163-1178, doi:10.5194/nhess-111163-2011, 2011.

Farges, T. and Blanc, E.: Characteristics of infrasound from lightning and sprites near thunderstorm areas, J. Geophys. Res., 115, A00E31, doi:10.1029/2009JA014700, 2010.

Füllekrug, M., Kolmasova, I., Santolik, O., Farges, T., Bor, J., Bennett, A., Parrot, M., Rison, W., Zanotti, F., Arnone, E., Mezentsev, A., Lan, R., Uhlir, L., Harrison, G., Soula, S., van der Velde, O., Pinçon, J.-L., Helling, C., and Diver, D.: Electron Acceleration Above Thunderclouds, Environ. Res. Lett., 8, 035027, doi:10.1088/1748-9326/8/3/035027, 2013.

Funatsu, B., Claud, C., and Chaboureau, J.-P.: Comparison between the Large-Scale Environments of Moderate and Intense Precipi- 
tating Systems in the Mediterranean Region, Mon. Weather Rev., 137, 3933-3959, 2009.

Gaffard, C., Nash, J., Atkinson, N., Bennett, A., Callaghan, G., Hibbett, E., Taylor, P., Turp, M., and Schulz, W.: Observing lightning around the globe from the surface, in: the Preprints, 20th International Lightning Detection Conference, Tucson, Arizona, 21-23, 2008.

Gallin, L.-J.: Caractérisation acoustique des éclairs d'orage, $\mathrm{PhD}$ dissertation, Université Pierre et Marie Curie, Paris, France, 2014.

Goodman, S. J., Buechler, D. E., Wright, P. D., and Rust, W. D.: Lightning and precipitation history of a microburst-producing storm, Geophys. Res. Lett., 15, 1185-1188, 1988.

Gurevich, A. V., Milikh, G. M., and Roussel-Dupre, G. M.: Runaway electron mechanism of air breakdown and preconditionning during a thunderstorm, Phys. Lett. A, 165, 463-468, 1992.

Helsdon Jr., J. and Farley, R.: A Numerical Modeling Study of a Montana Thunderstorm: 2. Model Results Versus Observations Involving Electrical Aspects, J. Geophys. Res., 92, 5661-5675, 1987.

Helsdon Jr., J. H., Gattaleeradapan, S., Farley, R. D., and Waits, C. C.: An examination of the convective charging hypothesis: Charge structure, electric fields, and Maxwell currents, J. Geophys. Res., 107, 4630, doi:10.1029/2001JD001495, 2002.

Holt, M. A., Hardaker, P. J., and McLelland, G. P.: A lightning climatology for Europe and the UK, 1990-99, Weather, 56, 290296, 2001.

Jacobson, A. R., Knox, S. O., Franzand, R., and Enemark, D. C.: FORTE observations of lightning radio-frequency signatures: Capabilities and basic results, Radio Sci., 34, 337-354, 1999.

Kohn, M., Galanti, E., Price, C., Lagouvardos, K., and Kotroni, V.: Now-Casting Thunderstorms in the Mediterranean Region using Lightning Data, Atmos. Res., 100, 489-502, 2011.

Kotroni, V. and Lagouvardos, K.: Lightning occurrence in relation with elevation, terrain slope and vegetation cover in the Mediterranean, J. Geophys. Res., 113, D21118, doi:10.1029/2008JD010605, 2008.

Krehbiel, P. R., Thomas, R. J., Rison, W., Hamlin, T., Harlin, J., and Davis, M.: GPS-based mapping system reveals lightning inside storms, EOS, 81, 21-25, 2000.

Kummerow, C., Barnes, W., Kozu, T., Shiue, J., and Simpson, J.: The tropical rainfall measuring mission (TRMM) sensor package, J. Atmos. Ocean. Tech., 15, 809-817, 1998.

Lagouvardos, K., Kotroni, V., Betz, H.-D., and Schmidt, K.: A comparison of lightning data provided by ZEUS and LINET networks over Western Europe, Nat. Hazards Earth Syst. Sci., 9, 1713-1717, doi:10.5194/nhess-9-1713-2009, 2009.

Lagouvardos, K., Kotroni, V., Defer, E., and Bousquet, O.: Study of a heavy precipitation event over southern France, in the frame of HYMEX project: Observational analysis and model results using assimilation of lightning, Atmos. Res., 134, 45-55, 2013.

Light, T. E., Suszcynsky, D. M., and Jacobson, A. R.: Coincident radio frequency and optical emissions from lightning, observed with the FORTE satellite, J. Geophys. Res., 106, 28223-28231, doi:10.1029/2001JD000727, 2001.

MacGorman, D. R. and Rust, W. D.: The electrical nature of storms, Oxford University Press, New York, 422 pp., 1998.
MacGorman, D. R., Few, A. A., and Teer, T. L.: Layered lightning activity, J. Geophys. Res., 86, 9900-9910, doi:10.1029/JC086iC10p09900, 1981.

MacGorman, D. R., Burgess, D. W., Mazur, V., Rust, W. D., Taylor, W. L., and Johnson, B. C.: Lightning rates relative to tornadic storm evolution on 22 May 1981, J. Atmos. Sci., 46, 221-250, 1989.

Mäkelä, A., Tuomi, T. J., and Haapalainen, J.: A decade of high-latitude lightning location: Effects of the evolving location network in Finland, J. Geophys. Res., 115, D21124, doi:10.1029/2009JD012183, 2010.

Mansell, E. R., MacGorman, D. R., Ziegler, C. L., and Straka, J. M.: Simulated three-dimensional branched lightning in a numerical thunderstorm model, J. Geophys. Res., 107, 4075, doi:10.1029/2000JD000244, 2002.

Marshall, T. C., Stolzenburg, M., Maggio, C. R., Coleman, L. M., Krehbiel, P. R., Hamlin, T., Thomas, R. J., and Rison, W.: Observed electric fields associated with lightning initiation, Geophys. Res. Lett., 32, L03813, doi:10.1029/2004GL021802, 2005.

Molinié, G., Pinty, J.-P., and Roux, F.: Some explicit microphysical and electrical aspects of a Cloud Resolving Model: Description and thunderstorm case study, C. R. Physique, 3, 1-20, 2002.

Montanyà, J., Soula, S., and Pineda, N.: A study of the total lightning activity in two hailstorms, J. Geophys. Res., 112, D13118, doi:10.1029/2006JD007203, 2007.

Montanyà, J., Soula, S., Murphy, M., March, V., Aranguren, D., Solà, G., and Romero, D.: Estimation of charge neutralized by negative cloud-to-ground flashes in Catalonia thunderstorms, J. Electrostat., 67, 513-517, 2009.

Orville, R. E., Huffines, G. R., Burrows, W. R., and Cummins, K. L.: The North American Lightning Detection Network (NALDN) - Analysis of Flash Data: 2001-09, Mon. Weather Rev., 139, 1305-1322, 2011.

Pinty, J.-P., Barthe, C., Defer, E., Richard, E., and Chong, M.: Explicit simulation of electrified clouds: from idealized to real case studies, Atmos. Res., 123, 82-92, 2013.

Poeppel, K.: A 3D Lightning parameterization with branching and charge induction, Master's thesis, S. D. Sch. of Mines and Technol., Rapid City, 2005.

Price, C., Yair, Y., Mugnai, A., Lagouvardos, K., Llasat, M. C., Michaelides, S., Dayan, U., Dietrich, S., Di Paola, F., Galanti, E., Garrote, L., Harats, N., Katsanos, D., Kohn, M., Kotroni, V., Llasat-Botija, M., Lynn, B., Mediero, L., Morin, E., Nicolaides, K., Rozalis, S., Savvidou, K., and Ziv, B.: Using lightning data to better understand and predict flash floods in the Mediterranean, Surv. Geophys., 32, 733-751, 2011.

Proctor, D. E.: VHF radio pictures of cloud flashes, J. Geophys. Res., 86, 4041-4071, 1981.

Rison, W., Thomas, R. J., Krehbiel, P. R., Hamlin, T., and Harlin, J.: A GPS-based Three-Dimensional Lightning Mapping System: Initial Observations in Central New Mexico, Geophys. Res. Lett., 26, 3573-3576, 1999.

Rust, W. D., MacGorman, D. R., Bruning, E. C., Weiss, S. A., Krehbiel, P. R., Thomas, R. J., Rison, W., Hamlin, T., and Harlin, J.: Inverted-polarity electrical structures in thunderstorms in the Severe Thunderstorm Electrification and Precipitation Study (STEPS), Atmos. Res., 76, 247-271, 2005. 
Saunders, C. P. R., Keith, W. D., and Mitzeva, P. P.: The effect of liquid water on thunderstorm charging, J. Geophys. Res., 96, 11007-11017, 1991.

Schroeder, V., Baker, M. B., and Latham, J.: A model study of corona emission from hydrometeors, Q. J. Roy. Meteor. Soc., 125, 1681-1693, 1999.

Schulz, W. and Saba, M. M. F.: First Results of Correlated Lightning Video Images and Electric Field Measurements in Austria, $\mathrm{X}$ International Symposium on Lightning Protection (SIPDA), Curitiba, Brazil, November, 2009.

Schulz, W., Lackenbauer, B., Pichler, H., and Diendorfer, G.: LLS Data and Correlated Continuous E-Field Measurements, VIII International Symposium on Lightning Protection (SIPDA), Sao Paulo, Brazil, 2005.

Schulz, W., Poelman, D., Pedeboy, S., Vergeiner, C., Pichler, H., Diendorfer, G., and Pack, S.: Performance validation of the European Lightning Location System EUCLID, International Colloquium on Lightning and Power Systems (CIGRE), Lyon, France, 2014.

Schultz, C., Petersen, W. A., and Carey, L. D.: Lightning and Severe Weather: A Comparison between Total and Cloud-toGround Lightning Trends, Weather Forecast., 26, 744-755, doi:10.1175/WAF-D-10-05026.1, 2011.

Shao, X.-M. and Krehbiel, P. R.: The spatial and temporal development of intracloud lightning, J. Geophys. Res., 101, 2664126668, 1996.

Skamarock, W. C., Klemp, J. B., Dudhia, J., Gill, D. O., Barker, D. M., Duda, M. G., Huang, X.-Y., Wang, W., and Powers, J. G.: A description of the Advanced Research WRF version 3, NCAR Tech. Note NCAR/TN-475 + STR, 113 pp., 2008.

Smith D. A., Eack, K. B., Harlin, J., Heavner, M. J., Jacobson, A. R., Massey, R. S., Shao, X. M., and Wiens, K. C.: The Los Alamos Sferic Array: A research tool for lightning investigations, J. Geophys. Res., 107, 4183, doi:10.1029/2001JD000502, 2002.

Stephens, G. L., Vane, D. G., Boain, R. J., Mace, G. G., Sassen, K., Wang, Z., Illingworth, A. J., O'connor, E. J., Rossow, W. B., Durden, S. L., Miller, S. D., Austin, R. T., Benedetti, A., Mitrescu, C., and The Cloudsat Science Team: The Cloudsat mission and the A-Train, B. Am. Meteorol. Soc., 83, 1771-1790, doi:10.1175/BAMS-83-12-1771, 2002.
Stolzenburg, M., Rust, W. D., and Marshall, T. C.: Electrical structure in thunderstorm convective regions. 3. Synthesis, J. Geophys. Res., D103, 14097-14108, 1998.

Soula, S. and Georgis, J. F.: Surface electrical field evolution below the stratiform region of MCS storms, Atmos. Res., 132-133, 264-277, 2013.

Soula, S., Chauzy, S., Chong, M., Coquillat, S., Georgis, J. F., Seity, Y., and Tabary, P.: Surface precipitation current produced by convective rains during MAP, J. Geophys. Res., 108, 4395, doi:10.1029/2001JD001588, 2003.

Standler, R. B. and Winn, W. P.: Effects of coronae on electric fields beneath thunderstorms, Q. J. Roy. Meteor. Soc., 105, 285-302, 1979.

Takahashi, T.: Riming electrification as a charge generation mechanism in thunderstrom, J. Atmos. Sci., 35, 1536-1548, 1978.

Thomas, R. J., Krehbiel, P.R., Rison, W., Hunyady, S.J., Winn, W.P., Hamlin, T., and Harlin, J.: Accuracy of the Lightning Mapping Array, J. Geophys. Res., 109, D14207, doi:10.1029/2004JD004549, 2004.

Williams, E., Boldi, B., Matlin, A., Weber, M., Hodanish, S., Sharp, D., Goodman, S., Raghavan, R., and Buechler, D.: The behavior of total lightning activity in severe Florida thunderstorms, Atmos. Res., 51, 245-265, 1999.

Yair, Y., Lynn, B., Price, C., Kotroni, V., Lagouvardos, K., Morin, E., Mugnai, A., and Llasat, M. C.: Predicting the potential for lightning activity in Mediterranean storms based on the Weather Research and Forecasting (WRF) model dynamic and microphysical fields, J. Geophys. Res.-Atmos., 115, D04205, doi:10.1029/2008JD010868, 2010.

Ziegler, C. L., MacGorman, D. R., Dye, J. E., and Ray, P. S.: A model evaluation of noninductive graupel-ice charging in the early electrification of a mountain thunderstorm, J. Geophys. Res., 96, 12833-12855, 1991. 